\title{
Food flora in 17th century northeast region of Brazil in Historia Naturalis Brasiliae
}

\author{
Maria Franco Trindade Medeiros ${ }^{1 *}$ and Ulysses Paulino Albuquerque ${ }^{2}$
}

\begin{abstract}
Background: This article reports historical ethnobotany research conducted from a study of the work Historia Naturalis Brasiliae (Natural History of Brazil), authored by Piso and Marcgrave and published in 1648, with main focus on Caatinga of northeast region of Brazil.

Methods: Focusing the content analysis on the section dedicated to plant species with multiple uses, Marcgrave's contribution to the aforementioned work, this research had the following objectives: the retrieval of 17th century knowledge about the food uses of the flora in the northeast region of Brazil, including the taxonomic classifications; the identification of plant parts, their modes of consumption and the ethnic group of consumers; and the verification of the use of these species over time.

Results: The use of 80 food species at the time of the publication of the work is indicated, some of which are endemic to the Caatinga, such as "umbu" (Spondias tuberosa Arruda), "mandacaru" (Cereus jamacaru DC.) and "carnauba" (Copernicia cerifera Mart.). It is noticeable that among the species listed by Marcgrave, some species still lack current studies indicating their real nutritional value. The present study is an unprecedented work because it introduces, in a systematic way, the food plants described in a study of 17th century Brazil.

Conclusions: Finally, this study makes information about plants consumed in the past accessible, aiming to provide material for studies that could develop new food products today.
\end{abstract}

Keywords: Food species, Marcgrave, 17th century, Brazil, Historical ethnobotany, Ethnobiology

\section{Background}

Researches based on historical sources of the food plants used on the past by the humanity is a challenge, especially when we are talking about the American's History, because the sources from this continent are scattered and scarce. Therefore, the ethnobotanical research with its historical point of view starts from the past sources in order to have an actual interpretation of the historical documents.

In recent years, food plants have been addressed in ethnobotanical research, focusing on the factors that influence the knowledge of human populations regarding these resources, but not properly utilizing these historical sources. In semiarid region of South America, aspects such as modes of cultural transmission of knowledge and

\footnotetext{
* Correspondence: mariaftm@hotmail.com

'Universidade Federal de Campina Grande, Campus de Cuité, Centro de Educação e Saúde, Unidade Acadêmica de Educação, Departamento de Ciências Biológicas, Olho D’Água da Bica s/n, Cuité, Paraíba CEP: 58175-000, Brazil

Full list of author information is available at the end of the article
}

the influence of ecological variables on the use of plants, including the time spent in the gathering process, soil deterioration due to grazing and nutritional constituents, have been identified and investigated as important factors in this dynamic of knowledge associated to food plants, especially on the semiarid region of Argentina see for example [1-8].

Particularly regarding Brazil, among the small number of studies devoted to the record of the knowledge and use of food plants today, those developed by [9-16] can be mentioned. There are historical studies of plants used for food, such as those conducted by [17-19], addressing the issue of emergency food to combat hunger in the Caatinga region (Northeast Brazil). The lack of information about food plants in the past is attributed to the methodological difficulty in accessing historical documents. Nowadays these methodological issues comes from the difficulty in accessing these specific information of the local population [20] because these persons underutilize 
the food plants of certain environments, considering the plants edible only in subsistence situations [21]. In addition, plants used on an emergency basis are characterised as being of low nutritional quality and having an unpleasant taste [22], which contributes to maintaining a standard of local consumption that is restricted to species from environments that present hostile natural conditions.

Currently, there are few published Brazilian ethnobotanical works and particularly few that take historical documents as records of the knowledge of food flora in past centuries. Given this context, it becomes obvious that there is a lack of knowledge on the food potential of Brazilian flora species, not only in the present moment but also in the past, when it is considered all the richness and potential of the Brazilian flora to be researched and valued. In this field the historical analysis still needs a more strong support to develop researches. The present research has been developed to fill this absence of works on this theme and to identify a great source of documents for accessing information on the knowledge of the food flora of Brazil.

As a source of historical research on the flora of the Brazilian Northeastern Region, the extensive contribution by Guilherme Piso and Jorge Marcgrave, titled Historia Naturalis Brasiliae (Natural History of Brazil), published for the first time in 1648, is mentioned [23]. This work is a milestone, and it represents a truly scientific effort to make the flora and fauna of Brazil known [24]. Piso's research concentrated on the medicinal applications of plant species. Marcgrave took as his main work a more comprehensive inquiry into botanical and zoological studies. In his writings, Marcgrave discusses in detail the useful plants of the northeast region of Brazil.

Taking this 17th century written source as a reference, the present study had the following objectives: 1 . to retrieve the knowledge of food plants recorded by Marcgrave in the 17th century, updating the taxonomic identification of the reported species and verifying their presence in contemporary food practice; 2 . to identify the parts of the plant used as a food resource as well as the mode of consumption of these species and determine whether there was any relation between these aspects with respect to mitigating and/or removing any undesirable effects of the vegetative organ consumed; and 3. to identify the ethnic groups mentioned by Marcgrave as consumers of these plants. The present study is an unprecedented work because it introduces, in a systematic way, the food plants described in 17th century Brazil. Finally, this study increases the accessibility of information about plants consumed in the past, aiming to provide context for studies of potential new food products today.

Brief biographical review of the author - Jorge Marcgrave Through the writings of Moreira and Urban [25,26], it is possible to illuminate the life of Marcgrave. Of German origin, he was born in Liebstadt, in Saxony, on September 20, 1610. At 17 years of age, he joined the University of Lipsi and several others, where for six years he devoted himself to the study of mathematics, medicine and natural sciences. He became an astronomer, chemist, physician, naturalist, geographer and architect.

The arrival of Marcgrave in Brazil was associated with the activities conducted by the West India Company, which operated through a monopoly granted by the Dutch government as an overseas offensive, aiming to destroy the colonial bases of Iberian wealth and power [27]. Founded in 1621, the Company followed the institutional model for the Americas and the western coast of Africa that was adopted by the East India Company in Asia from the early years of the 17 th century. Through this model, the Company promoted trade and colonisation in the mentioned regions, at the expense of the Spanish and Portuguese presence $[27,28]$.

Brazil also became a Dutch target due to a series of contingencies, including profits from sugar and Brazilwood, as well as its geographically strategic position, particularly the northeast, as an operations base against the Spanish and Portuguese fleet $[28,29]$. Portuguese groups that were established in Amsterdam to escape the persecution of the Inquisition in the Iberian Peninsula controlled the northeast sugar trade [28]. These Portuguese living in Amsterdam had been involved in the financing of the sugar agroindustry and the commercialisation of the product in European markets since the beginning of Northeast Brazil's colonisation [30]. These contacts with the Portuguese allowed the Dutch to know the economic and social conditions of the northeast coast, its ports and even the urban environment of the city of Olinda (in Pernambuco, NE Brazil). This connection was vital for executing attacks in Bahia, followed by those against Pernambuco.

In 1630, the army of the West India Company had already conquered Olinda and Recife (in Pernambuco). Seven years later, in 1637, Count João Maurício de Nassau assumed the government of Dutch Brazil, staying in Brazilian lands until 1644. Transferring the political centre from Olinda to Recife, Nassau assumed control over the region as governor-general [31]. This Dutch occupation of Northeast Brazil extended until the year 1654, when the Dutch were expelled by insurrection movements in Pernambuco [28].

Before leaving for Brazil, Nassau expressed to João de Laet, one of the best chroniclers of the West India Company, the desire for a scientific expedition to be organised to the domains that the Netherlands intended to settle in Brazil. For this reason, the Dutch physician and naturalist Guilherme Piso was appointed chief of the first strictly scientific mission issued by an European country in the lands of the "new world" [32]. In response to the order for a new doctor, which came from 
the administrative council in Pernambuco, Piso had been appointed by the Company as a doctor to come to Brazil to replace Dr. Guilherme van Millaene, Nassau's physician, who had died in 1637 [25]. Therefore, Piso would continue to implement a scientific mission in Brazil, with the aid of two trainees of medicine and mathematics, Cralitz and Marcgrave, in addition to a German painter who would illustrate their work, who remains anonymous today [32-34].

Marcgrave was well recommended by Laet, to whom he was close in the university circle, when Guilherme Piso invited him to join the expedition to Brazil. Together with Piso, Marcgrave was hired as an astronomer for this expedition [25,35].

At 28 years of age, Marcgrave left the Netherlands in January 1st, 1638, destined for the city of São Salvador, in Bahia. The scientific expedition embarked on the fleet established to reinforce the squad of Mauricio de Nassau to attack Bahia [25,32].

In Bahia, Marcgrave made topographical maps and toured the coast collecting vegetable and animal specimens. Following the team to Pernambuco, Marcgrave undertook much of his scientific action in this region. Marcgrave was in Brazil for six years, where he travelled from the São Francisco River to the State of Ceará, also staying in the states of Maranhão, Sergipe and Alagoas [36,37] (see Figure 1).

Although Marcgrave had planned his return to Europe for the year 1644, at this same time, he received orders from Mauricio de Nassau to proceed to Africa and undertake a scientific expedition similar to that conducted in Brazil [25,32]. In the preface of the first edition of Historia Naturalis Brasiliae, Laet reports that Marcgrave's trip to Brazil was marked by the tireless investigation of "new things". Marcgrave gave his herbarium to the Count of Nassau and went to Africa, dying shortly after arriving there, in July or August 1644 at 34 years of age.

\section{The historical source: Historia Naturalis Brasiliae}

Originally published in 1648, written by Guilherme Piso and co-authored by Jorge Marcgrave, Historia Naturalis Brasiliae is considered the Americas' first scientific treatise and, with regard to Brazil, the first report of the flora and the first medical botany of Brazil [35]. Piso and Marcgrave are thus considered the founders of the studies of nosology and natural history in Brazil [25]. Historia Naturalis Brasiliae described plant species that were only studied again 200 years after this scientific effort. Several authors have worked on the identification of these plants and/or cited information presented by Piso and Marcgrave, e.g., [39-42].

The original version is in the form of an in folio volume with discontinuous paging, written in Latin and published by Oficina Elsevier, and presents an inscription by Piso and Marcgrave to Count John Maurice of Nassau, governor of Dutch Brazil. The local flora, especially in the State of Pernambuco, constitute the majority

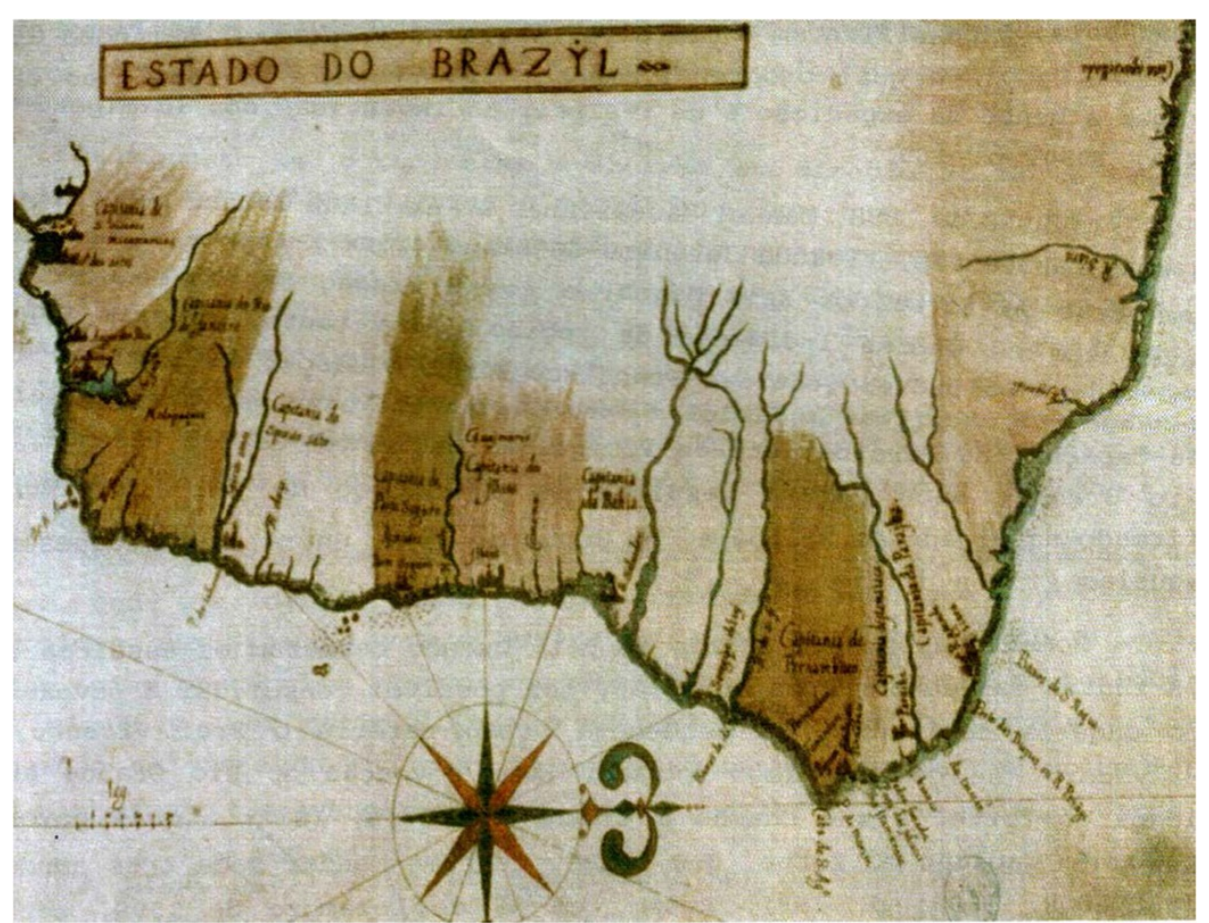

Figure 1 Map from the coast of Brazil, showing the Northeast coast at the left, where Margrave undertook his scientific action [38]. 
of the presented information. This area was the region where Marcgrave and Piso worked during most of their stay in Brazil. Urban [26] states that the authors worked in Pernambuco between the years 1640 and 1644, with few journeys to other states.

The first treatise of the work is authored by Piso and is titled De Medicina Brasiliensis, comprising four books dedicated to Brazilian tropical medicine, with the citation of 89 plants. After this treatise, Marcgrave's Historiae rerum Naturalium Brasiliae is presented, which was written by Laet, who also added additional information. Laet took charge of publishing this work and commented on Marcgrave's writings, stating that the original had been written in encrypted letters (cipher alphabet, Marcgrave's own invention) to protect the manuscripts and that the original "should be previously deciphered and transcribed with greater labour than someone would have the courage to take upon himself" [23]. Marcgrave's entire treatise includes eight books. The first three books contain the herbs, bushes and trees, making references to 279 plants. The other books contain zoology and provide astronomical, ethnographic and geographical comments.

The second edition, published 10 years after Historia Naturalis Brasiliae [23], is titled De Indiae utriusque re Naturali et Medica (1658) [43]. In this edition, only the plants presented in Piso's treatise are included, along with Marcgrave's writings on the geography, meteorology and ethnography of the region. Piso mentions 26 plants in addition to those previously considered.

For the present research on food plants, the Portuguese language version of the first edition of Historia Naturalis Brasiliae was used. In his treatise, Marcgrave not only considers medicinal plants, as Piso does, but also records industrial and home uses and curious properties of the studied organisms. Marcgrave collected specimens, sought to describe them in loco, prepared illustrations (drawings and watercolours) and gathered these "curious things" to his cabinet, creating a herbarium and a museum of "curious" objects. The Illustrations of the plants in the first edition are mostly his own, including the book's ornamentation [23]. Laet, while organising the edition of the work, ordered 14 drawings of Marcgrave's herbarium material and considers not only this set of illustrations but also those made by Marcgrave, distributing these prints throughout the text in a confusing way for the reader.

\section{Methods}

\section{Collection and analysis of historical ethnobotanical data}

The edition of Historia Naturalis Brasiliae published by Companhia Editora Nacional (Brazil) consists of two volumes published at different times: the first one, with Marcgrave's writings, published in 1942 and translated by José Procópio de Magalhães [36], and the second one, providing Piso's information, published in 1948 with a translation by Alexandre Correia. The work on this Portuguese version was located and consulted in the Blanche Knopf Central Library of the Joaquim Nabuco Foundation (FUNDAJ/Recife). Because the present study pertained to food plants, the effort focused on the study of Marcgrave's writings; therefore, the first book was used.

The study of Marcgrave's work was performed in two reading stages. First, a pre-reading of the source material was performed to establish an initial familiarity with the work and to designate the items that would compose the data collection chart. Subsequently, an in-depth reading was performed, with the concomitant transcription of information regarding food plants described by Marcgrave, opting to keep the palaeographic form of the text [44].

With the collected data, a database was created containing the popular names, scientific names, indicated food use, consumed part of the plant, mode of consumption, ethnic groups that used the plant as food, plant habit and whether there was any contraindication.

The current identification of the plants is hampered by the impossibility of consulting Marcgrave's and Piso's collections. Marcgrave's and Piso's herbaria were lost [35], and all that remains are some of Marcgrave's illustrations and other prints that Laet, organiser of the first edition, ordered to be made directly from the collected specimens. Because direct observation of the botanical material collected by Marcgrave was not possible, the scientific names reported in the work were updated and considered taxonomic tracks. The revision work conducted by Pickel and organised by [45] was adopted for an update of the identification of these Marcgravian plants. For each scientific name present in this study by Pickel, a taxonomic update was sought through consultation with the literature, the botany experts and databases of the Missouri Botanical Garden's VAST (VAScular Tropicos) nomenclatural database W3 Tropicos [46] and The International Plant Names Index (IPNI) [47].

The consultation of the recently mentioned revision by [45] of Piso's and Marcgrave's writings also intended to verify whether Piso mentioned the food use of those plants if the data presented by Marcgrave did not include this information. If there was an indication of food use, this additional information on Marcgravian plants was also incorporated into this work.

For historical contextualisation and relation to the life of Marcgrave and to verify the presence of the food plants mentioned by Marcgrave in contemporary food practice the following material relating to the period of Dutch rule in Brazil and to studies that included the relevant topics was consulted: food plants in a general manner, food plants present in ethnobotanical studies conducted in the Brazilian Northeast and assessments of the nutritional components of the food plant species mentioned in Historia Naturalis Brasiliae. The collection accessed is 
deposited at the National Library Foundation of Rio de Janeiro, the Marine Library São Paulo de Vasconcellos, from the Institute of Philosophy and Social Sciences of the Federal University of Rio de Janeiro (IFCS/UFRJ), and the Library of the National Museum of the Federal University of Rio de Janeiro (MN/UFRJ). Additionally, a search was performed for scientific works in the JSTOR (http://www. jstor.org), Scopus (http://www.scopus.com) and Scirus (http://www.scirus.com) databases in addition to specialised journals, using the keywords "etnobotânica" [ethnobotany] AND "plantas alimentícias" [food plants], as well as "etnobotânic" [ethnobotany] AND "Nordeste do Brasil" [Northeast of Brazil]. For research in ethnobotany, articles published in journals during the period from 2007 to 2013 were analysed. In these same databases, a survey was conducted for each species and popular name in the studied work.

\section{Results and discussion}

\section{Food plants referenced by Marcgrave}

Of the 279 plants mentioned in Historia Naturalis Brasiliae, 85 (23\%) had an indication of food use reported by Marcgrave [36] (Table 1). Among these food plants, it is possible to identify the taxonomic tracks of 80 species, contained within 74 genera and 44 families. For the term "herb", it was not possible to identify a taxonomic track because "herb" does not have an identification presented by Marcgrave himself ("quam Auctor non nominat", [23], p. 19) (Table 1). For two of the species displayed in the Table 1, actual botanical information linked to their popular names was kept separated. This form of data organisation has different causes. In the case of one of these two species, although the plants popularly designated by "nhua" and "pitomba" are treated separately by Marcgrave, Pickel [45] states that their descriptions are identical and would refer to the same species, identified as Talisia esculenta (A. St.- Hil.) Radlk. (Sapindaceae) (Table 1). The other species case was related to the terms "araticu ponhe" and "araticum apê" corresponded to two different species of Annonaceae, which are currently synonymous with Annona montana Macfad (Table 1).

The families with the largest numbers of species mentioned were Fabaceae (eight species); Anacardiaceae and Solanaceae (five species each), Arecaceae and Myrtaceae (four species each); and Cactaceae, Clusiaceae and Passifloraceae (three species each). Nevertheless, the above families had not corresponded in their entirely to the genera that include the largest number of species. The most varied genera in terms of species were Capsicum, Manihot, Passiflora, Psidium, Solanum and Spondias, with two species each. These genera include plants especially recognised by their fruits and appreciated for their taste, with the exception of Manihot and/or species used as spices in cooking.
The descriptions of the plants by Marcgrave include a comparison with European plants and aspects related to the habit, the shape and contours of the leaf and the shape of the flowers, fruits and seeds. Often, the entries include quotations from ancient and contemporary authors on botany, including Pliny [23-79], Dioscorides [33,34,36,37,44-90], Avicenna (980-1037), Garcia de la Huerta (1500-1568) and others. This inclusion of information might evidence the author's familiarity with the European flora and literature, as Pickel states [35], but it must also be considered that these inserts could have been authored by Laet while editing and publishing the books in 1648. Laet added comments to Marcgrave's studies, aiming to complement the information presented for each plant. This insertion of information can be proven, for example, in the note presented by Laet for the plant known as "Sesame, Gangila (term from Congo)" (Sesamum orientale L., Pedaliaceae), the excerpt for which is transcribed below: "[...] Note. Fray João de Santos in the History of Eastern Ethiopia, b. I chap. 4, states that in all these provinces, sesame is much found, most whitish and excellent, from which an oil is made [... ]" ([36], p. 21) (Table 1). Laet often provides information from other authors in his notes, even indicating the reading of Piso's treatise, present in the work Historia Naturalis Brasiliae.

Taking into consideration all the categories of use and respecting the ordering of plants by habit presented in Marcgrave's treatise, the herbs formed the largest group, followed by trees and bushes (with 137, 99 and 43 plants, respectively). If considering anything other than the list of food plants, tree species become the most significant, with $52 \%$ (43 plants) of the total, followed by herbs (32\%, 27 plants) and bushes (16\%, 13 plants). Marcgrave's systematic order of plants follows the division into herbs, bushes and trees. This organisation presented by the author is based on the artificial classification systems. Influenced by the philosophical premises concerning the principle of immutability of species, these classification systems aimed to be an efficient way of identifying samples without needing to show affinity relations between species $[48,49]$. Marcgrave establishes an ordering of the plants he considered, similar to the classification proposed during the 17th century by Andrea Caesalpino (1519-1603), who established one of the first classifications based on criteria of similarity and defined levels of taxonomic hierarchy.

\section{Parts of the plant used, mode of preparation and consumption of the food resources and ethnic group of consumers}

In addition to the vegetable organs of root, leaf, flower, fruit and seed, Marcgrave also used other terms to describe the parts of the plant used as food (Table 1). 
Table 1 Food species mentioned by Marcgrave in the work Historia Naturalis Brasiliae [36]

\begin{tabular}{llllll}
\hline Taxonomic track & Popular name & H & PU & MC & WU \\
\hline Amaranthaceae & & & & & \\
\hline Amaranthus viridis L. & Cararu; Bredos & $H$ & $\times$ & Cooked & \\
\hline $\begin{array}{lllll}\text { Iresine vermicularis } \\
\text { (L.) Moq. }\end{array}$ & Perexil & H & Le; Bar & $\begin{array}{l}\text { Cooked and seasoned, served with } \\
\text { beef and fish }\end{array}$ & Portuguese \\
& & & &
\end{tabular}

\section{Report of the naturalist}

This herb is cooked as a vegetable in the same manner as chard, has a good taste and easily softens when cooked (HNB, p. 13) beef and fish

The leaves and branches, cut short and cooked with a little vinegar, can be seasoned and preserved as a pickle to be eaten with beef and fish. These parts have great flavour and are highly valued by the Portuguese: they increase appetite, develop urine and open the oppilation of the viscera (HNB, p 14)

\section{Anacardiaceae}

Anacardium occidentale L. Acaiaiba; Acaiuiba $\operatorname{Tr} \mathrm{Nu} ; \mathrm{Fr}$ As wine and fresh Indians

The Indians appreciate more the nut for food than this fruit, from which they extract a wine (HNB, p. 94-95)

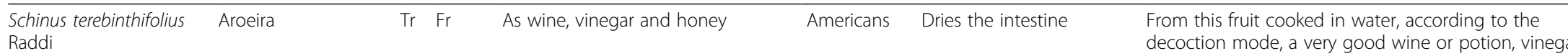
or honey are made (HNB, p. 90-91)

\begin{tabular}{|c|c|c|c|c|c|}
\hline Spondias purpurea $\mathrm{L}$. & Acaia; Ibametara & & Le & As spice & $x$ \\
\hline $\begin{array}{l}\text { Spondias tuberosa } \\
\text { Arruda* }\end{array}$ & Umbú & $\mathrm{Tr}$ & $\begin{array}{l}\mathrm{Fr} ; \mathrm{Le} ; \\
\mathrm{Br}\end{array}$ & As beverage or fresh & $x$ \\
\hline
\end{tabular}

From the crushed new leaves, a seasoning of very pleasant flavour to roasted meats is made (HNB, p. 129)

The ripe fruit has a nice, bittersweet flavour, used like the leaves, i.e., as a beverage. When chewed, the root crumbles into a watery, fresh and palatable juice, being used by weary travellers as an admirable refreshment, resembling the "watermelon" regarding the sweetness and wholesomeness of water (HNB-M. p. 108; HNB-P., p. 77)

\begin{tabular}{|c|c|c|c|c|c|c|c|}
\hline $\begin{array}{l}\text { Tapirira guianensis } \\
\text { Aubl. }\end{array}$ & Copiiba & $\operatorname{Tr}$ & $\mathrm{Fr}$ & Fresh & Indians & $x$ & $\begin{array}{l}\text { The fruit is eaten by sucking the juice and discarding the } \\
\text { skin (HNB, p. 121) }\end{array}$ \\
\hline \multicolumn{8}{|l|}{ Annonaceae } \\
\hline \multirow[t]{2}{*}{$\begin{array}{l}\text { Annona montana } \\
\text { Macfad. }\end{array}$} & Araticu ponhe & $\operatorname{Tr}$ & $\mathrm{Fr}$ & $x$ & $x$ & $x$ & $\begin{array}{l}\text { The fruit is not edible unless it has fallen spontaneously } \\
\text { because it is then soft as porridge; the pulp resembles a } \\
\text { mass of leavened bread, to which a little honey has been } \\
\text { mixed, and tastes sweet and tangy spicy (HNB, p. 93) }\end{array}$ \\
\hline & Araticum apê & $\operatorname{Tr}$ & $\mathrm{Fr}$ & $x$ & $x$ & $x$ & $\begin{array}{l}\text { Acid-sweet, edible fruit, but wild and cold and therefore } \\
\text { not craved by all people (HNB-M, p. 94; HNB-P, p. 70; 142) }\end{array}$ \\
\hline Xylopia frutescens Aubl. & Ibira & $\operatorname{Tr}$ & $\mathrm{Fr}$ & Dried, as pepper & $x$ & $x$ & $\begin{array}{l}\text { Its fruit is oval with the size of a hazelnut, with an } \\
\text { aromatic and spicy taste; used dried and reduced, it } \\
\text { can substitute for pepper (HNB, p. 99-100) }\end{array}$ \\
\hline \multicolumn{8}{|l|}{ Apocynaceae } \\
\hline $\begin{array}{l}\text { Hancornia speciosa } \\
\text { Gomes }\end{array}$ & $\begin{array}{l}\text { Mangabiba; } \\
\text { Mangaiba }\end{array}$ & $\operatorname{Tr}$ & $\mathrm{Fr} ; \mathrm{S}$ & Fruit and seeds are eaten together & $x$ & $\begin{array}{l}\text { Fruits on the plant are } \\
\text { impregnated with an } \\
\text { acrid and bitter latex }\end{array}$ & $\begin{array}{l}\text { The fruits are not edible unless they fall from the tree } \\
\text { spontaneously; its pulp is soft as butter and has a very } \\
\text { nice and acidic taste, with seeds of albumen sweet } \\
\text { flavour (HNB, p. 121-123) }\end{array}$ \\
\hline
\end{tabular}


Table 1 Food species mentioned by Marcgrave in the work Historia Naturalis Brasiliae [36] (Continued)

\begin{tabular}{|c|c|c|c|c|c|c|c|}
\hline Araceae & & & & & & & \\
\hline $\begin{array}{l}\text { Colocasia esculenta } \\
\text { (L.) Schott }\end{array}$ & Taiaoba & $\mathrm{H}$ & $\mathrm{R}$ & Cooked & $x$ & $x$ & $\begin{array}{l}\text { Its root is eaten cooked like the potato; it is sweet, with a } \\
\text { remarkable flavour, similar to musk or violet (HNB, p. 36) }\end{array}$ \\
\hline $\begin{array}{l}\text { Montrichardia linifera } \\
\text { (Arruda) Schott }\end{array}$ & Aniga Iba & $\operatorname{Tr}$ & $\mathrm{Fr}$ & $x$ & Indians & $x$ & $\begin{array}{l}\text { This fruit is eaten in case of need; it is eaten in times of } \\
\text { hunger (HNB, p. 106) }\end{array}$ \\
\hline \multicolumn{8}{|l|}{ Arecaceae } \\
\hline $\begin{array}{l}\text { Attalea oleifera } \\
\text { Barb. Rodr. }\end{array}$ & Pindoba & $\operatorname{Tr}$ & $\mathrm{Fr}$ & The pulp is eaten with flour & Blacks & $x$ & It is eaten with flour by the blacks (HNB, p. 133-134) \\
\hline Cocos nucifera L. & $\begin{array}{l}\text { Inaia guacuiba; } \\
\text { Coqueiro }\end{array}$ & $\operatorname{Tr}$ & $\mathrm{Fr} ; \mathrm{B}$ & $\begin{array}{l}\text { The core of the ripe fruit is eaten and } \\
\text { the water is drunk; the milk extracted } \\
\text { from the core of the fruit is cooked } \\
\text { with rice for dessert; the bulb is eaten. } \\
\text { Honey, sugar, vinegar and wine are } \\
\text { also made }\end{array}$ & $x$ & $\begin{array}{l}\text { The wine is harmful } \\
\text { for the hydropics } \\
\text { and those who have } \\
\text { obstructed spleen }\end{array}$ & $\begin{array}{l}\text { The cavity is filled with a very pleasant water to drink; it is } \\
\text { sweet, cold and clear (HNB, p. 138-141) }\end{array}$ \\
\hline $\begin{array}{l}\text { Copernicia cerifera } \\
\text { Mart.* }\end{array}$ & $\begin{array}{l}\text { Carana iba; } \\
\text { Anana chi carirí }\end{array}$ & $\operatorname{Tr}$ & $\mathrm{Fr}$ & Fresh & $x$ & & Sweet after ripe (HNB-M, p. 62; HNB-P, p. 62) \\
\hline $\begin{array}{l}\text { Syagrus coronata } \\
\text { (Mart.) Becc. }\end{array}$ & Urucuri iba & $\operatorname{Tr}$ & S & $x$ & $x$ & $x$ & $\begin{array}{l}\text { Inside the fruit, there is a hard seed; an edible white nut } \\
\text { is found (HNB, p. 104) }\end{array}$ \\
\hline \multicolumn{8}{|l|}{ Bignoniaceae } \\
\hline Crescentia cujete L. & Cuiete; Cochine & $\operatorname{Tr}$ & $\mathrm{Fr}$ & The pulp is edible & $x$ & $x$ & $\begin{array}{l}\text { The unripe fruit encloses a white juicy pulp, with a smell } \\
\text { close to that of watercress, slightly sweet. The barbarians } \\
\text { eat this fruit in case of necessity (HNB, p. 123) }\end{array}$ \\
\hline \multicolumn{8}{|l|}{ Bixaceae } \\
\hline Bixa orellana $\mathrm{L}$. & Urucu & $\operatorname{Tr}$ & S & $\begin{array}{l}\text { The seeds are processed into a paste, } \\
\text { which is mixed with manioc pap }\end{array}$ & Indians & $x$ & $\begin{array}{l}\text { The paste of urucu has a good taste and is aromatic but } \\
\text { tastes a little bitter, being eaten with a porridge of manioc } \\
\text { called carimã (HNB, p. 61) }\end{array}$ \\
\hline \multicolumn{8}{|l|}{ Bromeliaceae } \\
\hline $\begin{array}{l}\text { Ananas sativus } \\
\text { Schult. \& Schult. f. }\end{array}$ & Nana; Ananas & $\mathrm{H}$ & $\mathrm{Fr}$ & Fresh and in conserved with sugar & Indians & $x$ & $\begin{array}{l}\text { The fruit has the sweetest smell and very pleasant flavour, } \\
\text { like strawberries, extremely juicy (HNB, p. 33) }\end{array}$ \\
\hline Bromelia karatas L. & $\begin{array}{l}\text { Nana brava; } \\
\text { Caraguata-acanga }\end{array}$ & $\mathrm{Bu}$ & $\mathrm{Fr}$ & $x$ & $x$ & $x$ & $\begin{array}{l}\text { Produces an edible fruit, with a length equivalent to five } \\
\text { fingers (HNB, p. 88) }\end{array}$ \\
\hline \multicolumn{8}{|l|}{ Cactaceae } \\
\hline Cereus jamacaru D.C.* & $\begin{array}{l}\text { lamacarú; Cardon; } \\
\text { Caxambú }\end{array}$ & $\operatorname{Tr}$ & $\mathrm{Fr}$ & Fresh & $x$ & $x$ & Edible fruit (HNB-M, p. 126; HNB-P, p. 99) \\
\hline $\begin{array}{l}\text { Hylocereus undatus } \\
\text { (Haw.) Britton \& Rose }\end{array}$ & lamacarú & $\mathrm{H}$ & $\mathrm{Fr}$ & Fresh & $x$ & $x$ & $\begin{array}{l}\text { Fruit with succulent, tasty flesh, filled with black seeds. } \\
\text { The whole internal part is eaten (HNB, p. 23-24) }\end{array}$ \\
\hline $\begin{array}{l}\text { Opuntia brasiliensis } \\
\text { (Willd.) Haw. }\end{array}$ & lamacarú & $\mathrm{Tr}$ & $\mathrm{Fr}$ & The fruit and the grains are edible & $x$ & $\begin{array}{l}\text { Dries the stomach and } \\
\text { provokes flatulence }\end{array}$ & $\begin{array}{l}\text { It is said that the fruit, when eaten with the grain, dries } \\
\text { the stomach; it provides good and pleasant nourishment } \\
\text { (HNB, p. 126-127) }\end{array}$ \\
\hline
\end{tabular}


Table 1 Food species mentioned by Marcgrave in the work Historia Naturalis Brasiliae [36] (Continued)

\begin{tabular}{|c|c|c|c|c|c|c|c|}
\hline Cannaceae & & & & & & & \\
\hline Canna indica $\mathrm{L}$. & Meeru & $\mathrm{H}$ & $\mathrm{R}$ & $x$ & Blacks & $x$ & The blacks eat the root $(H N B, p .4)$ \\
\hline \multicolumn{8}{|l|}{ Capparaceae } \\
\hline Crataeva tapia $\mathrm{L}$. & Tapiá & $\operatorname{Tr}$ & $\mathrm{Fr}$ & $x$ & $x$ & $x$ & The fruit is edible (HNB, p. 98) \\
\hline \multicolumn{8}{|l|}{ Caricaceae } \\
\hline Carica papaya L. & $\begin{array}{l}\text { Mamoeira; Papay; } \\
\text { Mamão }\end{array}$ & $\operatorname{Tr}$ & $\mathrm{Fr}$ & Raw or cooked & $x$ & $x$ & $\begin{array}{l}\text { The fruit can be eaten raw but is usually eaten cooked } \\
\text { alone or mixed with meat (HNB, p. 102-104) }\end{array}$ \\
\hline Jaracatia sp. & laracatiá & $\operatorname{Tr}$ & $\mathrm{Fr}$ & Raw or cooked & $x$ & $x$ & $\begin{array}{l}\text { When ripe, falls spontaneously and is eaten raw or } \\
\text { cooked (HNB, p. 128-129) }\end{array}$ \\
\hline \multicolumn{8}{|l|}{ Chrysobalanaceae } \\
\hline Chrysobalanus icaco L. & Guaieru; Guajeru & $\mathrm{Bu}$ & $\mathrm{Fr}$ & $x$ & $x$ & $x$ & This fruit has sweet white flesh; it is edible (HNB, p. 77) \\
\hline Couepia rufa Ducke & Guitiiba & $\operatorname{Tr}$ & $\mathrm{Fr}$ & $x$ & Indians & $x$ & $\begin{array}{l}\text { The pulp is eaten, but not the seed; the pulp is negligible } \\
\text { and gives the impression of having sand between the } \\
\text { teeth when chewed but has a sweet taste and good } \\
\text { smell, reminiscent of bread that has been recently } \\
\text { made (HNB, p. 114) }\end{array}$ \\
\hline \multicolumn{8}{|l|}{ Cleomaceae } \\
\hline $\begin{array}{l}\text { Cleome rosea } \\
\text { Valh ex DC. }\end{array}$ & Micambe de Angola & $\mathrm{H}$ & S & $x$ & Blacks & $x$ & Used by blacks as food (HNB, p. 10) \\
\hline \multicolumn{8}{|l|}{ Clusiaceae } \\
\hline $\begin{array}{l}\text { Clusia nemorosa } \\
\text { G. Mey. }\end{array}$ & $\begin{array}{l}\text { Coapoiba; } \\
\text { Pao gamelo }\end{array}$ & $\operatorname{Tr}$ & $\mathrm{Fr}$ & $x$ & $x$ & $x$ & $\begin{array}{l}\text { They are eaten by some but are not much appreciated } \\
\text { (HNB, p. 131-132) }\end{array}$ \\
\hline Platonia insignis Mart. & Ibacuri-pari & $\operatorname{Tr}$ & $\mathrm{Fr}$ & The pulp is edible & $x$ & $x$ & $\begin{array}{l}\text { The pulp of the fruit has an acrid and a slightly bitter } \\
\text { taste but is edible (HNB, p. 119) }\end{array}$ \\
\hline $\begin{array}{l}\text { Rheedia macrophylla } \\
\text { (Mart.) Planch. \& Triana }\end{array}$ & Ibacuru-pari & $\operatorname{Tr}$ & $\mathrm{Nu}$ & $x$ & Indians & $x$ & $\begin{array}{l}\text { The albumen, which is very white, is edible } \\
\text { (HNB, p. 119-120) }\end{array}$ \\
\hline \multicolumn{8}{|l|}{ Convolvulaceae } \\
\hline $\begin{array}{l}\text { Ipomoea batatas } \\
\text { (L.) Lam. }\end{array}$ & $\begin{array}{l}\text { letica; } \\
\text { Quiquoaquianputu; } \\
\text { Batata }\end{array}$ & $\mathrm{H}$ & Po & Cooked, roasted, as fermented drink & Indians & $x$ & $\begin{array}{l}\text { They are steamed or roasted in ashes and have a great } \\
\text { flavour, more preferable than the radish. The fresh potato, } \\
\text { when crushed and macerated in a little water, provides } \\
\text { a drink (HNB, p. 16-17) }\end{array}$ \\
\hline \multicolumn{8}{|l|}{ Cucurbitaceae } \\
\hline $\begin{array}{l}\text { Citrullus lanatus } \\
\text { (Thunb.) Matsum. } \\
\text { \& Nakai }\end{array}$ & Jaee; Balancia & $\mathrm{H}$ & $\mathrm{Fr}$ & $\begin{array}{l}\text { The fresh pulp is eaten, and the } \\
\text { water is drunk }\end{array}$ & $x$ & $x$ & $\begin{array}{l}\text { It has a juiciest pulp of good flavour; it has such a large } \\
\text { amount of sweet and cold water that, during the meal, } \\
\text { it may be taken as if it was in a glass (HNB, p. 22) }\end{array}$ \\
\hline Cucumis sp. & $\begin{array}{l}\text { Pepino Silvestre } \\
\text { do Brasil }\end{array}$ & $\mathrm{H}$ & $\mathrm{Fr}$ & $x$ & $x$ & $x$ & It is edible (HNB, p. 44) \\
\hline Cucurbita pepo L. & $\begin{array}{l}\text { lurum; Bóbora; } \\
\text { Pompoen }\end{array}$ & $\mathrm{H}$ & $\mathrm{Fr}$ & Roasted or cooked & $x$ & $x$ & $\begin{array}{l}\text { The boiled or baked fruit in the ashes has a good taste } \\
\text { (HNB, p. 44) }\end{array}$ \\
\hline
\end{tabular}


Table 1 Food species mentioned by Marcgrave in the work Historia Naturalis Brasiliae [36] (Continued)

\begin{tabular}{|c|c|c|c|c|c|c|c|}
\hline \multicolumn{8}{|l|}{ Dioscoreaceae } \\
\hline $\begin{array}{l}\text { Polynome alata } \\
\text { (L.) Salisb. }\end{array}$ & $\begin{array}{l}\text { Cará; Inhame } \\
\text { de São Thomé; } \\
\text { Quiquoaquicongo }\end{array}$ & $\mathrm{H}$ & $\mathrm{R}$ & Cooked or dried & $\begin{array}{l}\text { Inhabitants } \\
\text { from Guinea }\end{array}$ & $x$ & $\begin{array}{l}\text { The root, when cooked with butter or olive oil and } \\
\text { pepper, has a great flavour; it is dry and floury, and } \\
\text { thus, the people from Guinea eat it to replace } \\
\text { bread (HNB, p. 29) }\end{array}$ \\
\hline \multicolumn{8}{|l|}{ Euphorbiaceae } \\
\hline $\begin{array}{l}\text { Manihot esculenta } \\
\text { Crantz }\end{array}$ & $\begin{array}{l}\text { Maniiba; Mandijba; } \\
\text { Mandioca }\end{array}$ & $\mathrm{Bu}$ & R; Le & For preparing flour, pap, bread, cakes & Indians & $\begin{array}{l}\text { The milky and glutinous } \\
\text { juice of the root kills all } \\
\text { living beings }\end{array}$ & $\begin{array}{l}\text { The leaves, when pounded and cooked with oil or } \\
\text { butter, are edible (HNB, p. 65-67) }\end{array}$ \\
\hline $\begin{array}{l}\text { Manihot glaziovii } \\
\text { Müll. Arg. }\end{array}$ & Maniçoba; Mandijba & $\operatorname{Tr}$ & Le & Cooked & $x$ & $x$ & $\begin{array}{l}\text { The leaves, well crushed with a pestle in a wood mortar } \\
\text { and then cooked with olive oil and butter, are eaten like } \\
\text { cooked spinach (HNB, p. 68) }\end{array}$ \\
\hline \multicolumn{8}{|l|}{ Fabaceae } \\
\hline Arachis hypogaea L. & Mundubi & $\mathrm{H}$ & $\mathrm{R}$ & Cooked & $x$ & $\begin{array}{l}\text { Eaten in a large amount } \\
\text { cause headaches }\end{array}$ & $\begin{array}{l}\text { Are served to eat cooked and presented as dessert } \\
(H N B, \text { p. 37) }\end{array}$ \\
\hline Cajanus cajan (L.) Huth & Comanda guira & $\mathrm{Bu}$ & $\mathrm{S}$ & Cooked & Indians & Laxative & Has a good taste when cooked (HNB, p. 62) \\
\hline Geoffraea sp. & Umari & $\operatorname{Tr}$ & $\mathrm{Fr}$ & Cooked & $x$ & $\begin{array}{l}\text { The unripe fruit is harmful } \\
\text { for the stomach }\end{array}$ & $\begin{array}{l}\text { Eaten unripe is harmful to the stomach and causes } \\
\text { vomiting, so it is usually cooked and mashed with the } \\
\text { seeds in the mortar, and the paste is eaten replacing } \\
\text { bread or flour in dishes of beef and fish (HNB, p. 121) }\end{array}$ \\
\hline $\begin{array}{l}\text { Hymenaea martiana } \\
\text { Hayne }\end{array}$ & Jetaiba & $\operatorname{Tr}$ & $\mathrm{Fr}$ & $x$ & Indians & $x$ & $\begin{array}{l}\text { The flesh, whose taste is not disregarded, is eaten } \\
\text { (HNB, p. 101) }\end{array}$ \\
\hline Inga vera Willd. & Inga & $\operatorname{Tr}$ & $\mathrm{Fr}$ & Fresh & Indians & $x$ & This edible fruit is palatable (HNB, p. 111) \\
\hline $\begin{array}{l}\text { Lablab purpureus } \\
\text { (L.) Sweet }\end{array}$ & Mandatia & $\mathrm{H}$ & S & Cooked & $x$ & $x$ & $\begin{array}{l}\text { The seeds are edible, with an excellent taste if mixed } \\
\text { with spices and cooked (HNB, p. 52) }\end{array}$ \\
\hline $\begin{array}{l}\text { Phyllocalyx edulis } \\
\text { O. Berg. }\end{array}$ & Ibiruba & $\operatorname{Tr}$ & $\mathrm{Fr}$ & $x$ & $x$ & $x$ & $\begin{array}{l}\text { The fruit has a juicy pulp, with an acidic taste and slowly } \\
\text { embittering, not unpleasant, and has a sweet and grapey } \\
\text { smell; the seed is discarded, the rest is eaten; it is an } \\
\text { excellent fruit and can be eaten in a large amount } \\
\text { without inconvenience (HNB, p. 132) }\end{array}$ \\
\hline $\begin{array}{l}\text { Voandzeia subterranea } \\
\text { (L.) DC. }\end{array}$ & Mandubi d'Angola & $\mathrm{H}$ & $\mathrm{R}$ & Roasted & $x$ & $x$ & Edible roots (HNB, p. 43-44) \\
\hline \multicolumn{8}{|l|}{ Heliconiaceae } \\
\hline $\begin{array}{l}\text { Heliconia vaginalis } \\
\text { Benth. }\end{array}$ & $\begin{array}{l}\text { Aglutiguepo-obi; } \\
\text { Acutitiguepo; } \\
\text { Cotitepooba }\end{array}$ & $\mathrm{H}$ & $\mathrm{R}$ & Roasted and cooked & $x$ & $x$ & $\begin{array}{l}\text { The root is roasted or boiled for food in times of hunger } \\
(H N B, \text { p. } 53)\end{array}$ \\
\hline \multicolumn{8}{|l|}{ Lamiaceae } \\
\hline Vitex rufescens A. Juss. & Ibapurunga & $\operatorname{Tr}$ & $\mathrm{Fr}$ & Fresh & Indians & $x$ & $\begin{array}{l}\text { These fruits are eaten without the bark; they are sweet } \\
\text { but not too manifest (HNB, p. 116) }\end{array}$ \\
\hline \multicolumn{8}{|l|}{ Lecythidaceae } \\
\hline $\begin{array}{l}\text { Lecythis pisonis } \\
\text { Cambess. }\end{array}$ & laçapucaya & $\operatorname{Tr}$ & $\mathrm{Nu}$ & Raw and roasted & $x$ & $x$ & $\begin{array}{l}\text { The nuts have an albumen with great flavour, which is } \\
\text { eaten raw or roasted (HNB, p. 128) }\end{array}$ \\
\hline
\end{tabular}


Table 1 Food species mentioned by Marcgrave in the work Historia Naturalis Brasiliae [36] (Continued)

\begin{tabular}{|c|c|c|c|c|c|c|c|}
\hline Malpighiaceae & & & & & & & \\
\hline Byrsonima sp. & Mureci & $\operatorname{Tr}$ & $\mathrm{Fr}$ & $x$ & Indians & $x$ & $\begin{array}{l}\text { The fruit of this tree consists of berries with the figure } \\
\text { and size of briar fruits and are edible (HNB, p. 118) }\end{array}$ \\
\hline \multicolumn{8}{|l|}{ Malvaceae } \\
\hline Hibiscus esculentus L. & $\begin{array}{l}\text { Quingombo; } \\
\text { Quillombo }\end{array}$ & $\mathrm{H}$ & $\mathrm{Fr}$ & Cooked & $x$ & $x$ & $\begin{array}{l}\text { This pericarp smells like pods when green and have a } \\
\text { sweetish taste; it is entirely cooked in water and is eaten } \\
\text { cooked with olive oil, vinegar and pepper, the more ripe, } \\
\text { the better to cook (HNB, p. 31) }\end{array}$ \\
\hline \multicolumn{8}{|l|}{ Marantaceae } \\
\hline $\begin{array}{l}\text { Saranthe marcgravii } \\
\text { Pickel }\end{array}$ & Tamoatarana & $\mathrm{H}$ & B & Cooked & $x$ & $x$ & $\begin{array}{l}\text { It is cooked and eaten like (sweet) potatoes; it has a good } \\
\text { flavour (HNB, p. 53-54) }\end{array}$ \\
\hline \multicolumn{8}{|l|}{ Melastomataceae } \\
\hline $\begin{array}{l}\text { Clidemia hirta } \\
\text { (L.) D. Don }\end{array}$ & Caaghiyuyo & $\mathrm{Bu}$ & $\mathrm{Fr}$ & Fresh or as juice & Ethiopians & $x$ & $\begin{array}{l}\text { Fruits, with a sweet taste, are eaten by the Ethiopians and } \\
\text { provide a juice more or less like the blueberry (HNB, p. 59) }\end{array}$ \\
\hline $\begin{array}{l}\text { Mouriri pusa Gardner } \\
\text { ex Gardner }\end{array}$ & Curuiri & $\operatorname{Tr}$ & $\mathrm{s}$ & $x$ & Indians & $x$ & It is edible and often enjoyable (HNB, p. 109-110) \\
\hline \multicolumn{8}{|l|}{ Moraceae } \\
\hline $\begin{array}{l}\text { Maclura tinctoria (L.) } \\
\text { D. Don ex Steud. }\end{array}$ & Tataiiba & $\operatorname{Tr}$ & $\mathrm{Fr}$ & Fresh or with sugar or wine & $x$ & $x$ & $\begin{array}{l}\text { The fruits are juicy and sweet and are eaten as } \\
\text { blackberries, pure or with sugar and wine (HNB, p. 119) }\end{array}$ \\
\hline \multicolumn{8}{|l|}{ Musaceae } \\
\hline Musa paradisiaca L. & $\begin{array}{l}\text { Pacoeira; } \\
\text { Quibuaaquitiba }\end{array}$ & $\operatorname{Tr}$ & $\mathrm{Fr}$ & Fresh, cooked or fried & $x$ & $x$ & $\begin{array}{l}\text { It has a good flavour and is eaten pure, with manioc flour, } \\
\text { baked or fried in olive oil or butter (HNB, p. 137-138) }\end{array}$ \\
\hline \multicolumn{8}{|l|}{ Myrtaceae } \\
\hline $\begin{array}{l}\text { Campomanesia } \\
\text { dichotoma (O. Berg) } \\
\text { Mattos }\end{array}$ & Ibabiraba & $\operatorname{Tr}$ & $\mathrm{Fr} ; \mathrm{S}$ & $x$ & Indians & $x$ & $\begin{array}{l}\text { Its pulp and seeds are eaten together; the taste is sweet, } \\
\text { somewhat mixed with resin (HNB, p. 117) }\end{array}$ \\
\hline Eugenia uniflora L.* & $\begin{array}{l}\text { Ibipitanga; Ibipitinga; } \\
\text { Ubapitanga }\end{array}$ & $\operatorname{Tr}$ & $\mathrm{Fr}$ & $x$ & $x$ & $x$ & $\begin{array}{l}\text { Very juicy fruit with red pulp and a hot taste, with a bit } \\
\text { of pepper; it is an attractive dessert (HNB-M, p. 116; } \\
\text { HNB-P, p. 121) }\end{array}$ \\
\hline Psidium guineense Sw. & Araça-iba & $\mathrm{Bu}$ & $\mathrm{Fr}$ & In conserve with sugar (marmalade) & $x$ & $x$ & It tastes good, sweet and astringent (HNB, p. 62) \\
\hline Psidium guajava $\mathrm{L}$. & $\begin{array}{l}\text { Guayaba; } \\
\text { Granaet-peeren }\end{array}$ & $\operatorname{Tr}$ & $\mathrm{Fr} ; \mathrm{S}$ & Cooked and raw & $x$ & $\begin{array}{l}\text { It is laxative when } \\
\text { ingested, being thus } \\
\text { unhealthy if eaten } \\
\text { excessively }\end{array}$ & $\begin{array}{l}\text { The pulp contains small seeds, which are eaten together; } \\
\text { the fruits are small and with a pleasant flavour; it is great } \\
\text { both raw and cooked (HNB, p. 104-105) }\end{array}$ \\
\hline \multicolumn{8}{|l|}{ Passifloraceae } \\
\hline $\begin{array}{l}\text { Passiflora cincinnata } \\
\text { Mast. }\end{array}$ & Murucujá & $\mathrm{Bu}$ & $\mathrm{Fr}$ & $x$ & $x$ & $x$ & $\begin{array}{l}\text { The fruit is cut transversely when one wants to eat it, } \\
\text { being recommended both for its scent and for its taste } \\
\text { (HNB, p. } 71 \text { ) }\end{array}$ \\
\hline $\begin{array}{l}\text { Passiflora } \\
\text { quadrangularis L. }\end{array}$ & $\begin{array}{l}\text { Murucuia-guaçú; } \\
\text { Gauinumbi acaiuba }\end{array}$ & $\mathrm{Bu}$ & $\mathrm{Fr} ; \mathrm{S}$ & The pulp is sucked with the seeds & $x$ & $x$ & $\begin{array}{l}\text { The smell and flavour of the fruit are sweet and mild; to } \\
\text { eat it, it is cut crosswise, and the pulp is slightly } \\
\text { separated from the pericarp (HNB, p. 70) }\end{array}$ \\
\hline
\end{tabular}


Table 1 Food species mentioned by Marcgrave in the work Historia Naturalis Brasiliae [36] (Continued)

\begin{tabular}{|c|c|c|c|c|c|c|c|}
\hline \multicolumn{8}{|l|}{ Pedaliaceae } \\
\hline Sesamum orientale L. & $\begin{array}{l}\text { Sésamo; Gangila; } \\
\text { Girgilim }\end{array}$ & $\mathrm{H}$ & $\mathrm{S}$ & $\begin{array}{l}\text { Oil extracted from the seed, and } \\
\text { residuals eaten with corn }\end{array}$ & Blacks & $x$ & $\begin{array}{l}\text { An oil is produced, which is commonly eaten and } \\
\text { used (HNB, p. 21) }\end{array}$ \\
\hline \multicolumn{8}{|l|}{ Piperaceae } \\
\hline Piper marginatum Jacq. & Nhamdu; Betre & $\mathrm{Bu}$ & $\mathrm{Fr}$ & Dried & $x$ & $x$ & $\begin{array}{l}\text { Sun-dried fruits are sour as the best black pepper; it is } \\
\text { not a bad food and gives a good flavour (HNB, p. 75) }\end{array}$ \\
\hline \multicolumn{8}{|l|}{ Poaceae } \\
\hline $\begin{array}{l}\text { Arundo saccharifera } \\
\text { Garsault }\end{array}$ & Vubae; Tacomaree & $\mathrm{Bu}$ & $\mathrm{Cu}$ & To sweeten the food (produce sugar) & $x$ & $x$ & $\begin{array}{l}\text { The pith of the cane is solid, juicy, sweet and white } \\
\text { (HNB, p. 82) }\end{array}$ \\
\hline \multicolumn{8}{|l|}{ Portulacaceae } \\
\hline Portulaca oleracea L. & Caaponga & $\mathrm{H}$ & $x$ & Cooked & $x$ & $x$ & This herb is eaten cooked (HNB, p. 49) \\
\hline \multicolumn{8}{|l|}{ Rubiaceae } \\
\hline Genipa americana L. & lanipaba; lenipapo & $\operatorname{Tr}$ & $\mathrm{Fr} ; \mathrm{S}$ & Fresh or as wine & $x$ & $x$ & $\begin{array}{l}\text { From the acidic flavoured pulp, refreshing and with } \\
\text { a pleasant smell, a wine is squeezed; its grains or } \\
\text { seeds are also eaten with the flesh (HNB, p. 92-93) }\end{array}$ \\
\hline \multicolumn{8}{|l|}{ Sapindaceae } \\
\hline \multirow[t]{2}{*}{$\begin{array}{l}\text { Talisia esculenta } \\
\text { (A. St.-Hil.) Radlk. }\end{array}$} & Nhua & $\operatorname{Tr}$ & $\mathrm{Fr}$ & $x$ & $x$ & $x$ & $\begin{array}{l}\text { Fruit has a somewhat bitter taste; when ripe, it falls, } \\
\text { being picked up and eaten (HNB, p. 100) }\end{array}$ \\
\hline & Pitoma & $\operatorname{Tr}$ & $\mathrm{Fr}$ & The pulp is eaten & $x$ & $x$ & $\begin{array}{l}\text { The flesh tastes astringently acidic and is separated } \\
\text { from the bark, cut and eaten (HNB, p. 125) }\end{array}$ \\
\hline \multicolumn{8}{|l|}{ Sapotaceae } \\
\hline $\begin{array}{l}\text { Pouteria grandiflora } \\
\text { (A. DC.) Baehni }\end{array}$ & $\begin{array}{l}\text { Guiti-toroba; } \\
\text { Steen-appel }\end{array}$ & $\operatorname{Tr}$ & $\mathrm{Fr}$ & Ripe & Indians & $\begin{array}{l}\text { It is inedible before } \\
\text { ripe because it is replete } \\
\text { with acrid latex }\end{array}$ & $\begin{array}{l}\text { The fruit, when opened, exudes a strong disgusting } \\
\text { smell, like old grease, with a sweet tasting pulp; the } \\
\text { fruit is edible (HNB, p. 113-114) }\end{array}$ \\
\hline \multicolumn{8}{|l|}{ Solanaceae } \\
\hline Capsicum annuum L. & $\begin{array}{l}\text { Quiya uçu; Pimenta } \\
\text { grande; Pimentões }\end{array}$ & $\mathrm{H}$ & $\mathrm{Fr}$ & As spice & Indians & $x$ & $\begin{array}{l}\text { The Indians smash this pepper with salt and call this } \\
\text { mixture luquitayae, with which they season the food } \\
\text { at the time of the meal in the same way that we } \\
\text { use salt (HNB, p. 39) }\end{array}$ \\
\hline $\begin{array}{l}\text { Capsicum annuum var. } \\
\text { frutescens (L.) Kuntze }\end{array}$ & $\begin{array}{l}\text { Quiya cumari; } \\
\text { Quiyaqui; Pimenta } \\
\text { malagueta }\end{array}$ & $\mathrm{H}$ & $\mathrm{Fr}$ & $x$ & Indians & $x$ & $\begin{array}{l}\text { This fruit tastes very bitter, much spicier than the } \\
\text { other species (HNB, p. 39) }\end{array}$ \\
\hline Physalis peruviana $\mathrm{L}$. & Camarú & $\mathrm{H}$ & $\mathrm{Fr}$ & $x$ & $x$ & $x$ & $\begin{array}{l}\text { The fruit is edible and has a flavour similar to our } \\
\text { bladder cherry (HNB, p. 12) }\end{array}$ \\
\hline $\begin{array}{l}\text { Solanum agrarium } \\
\text { Sendtn. }\end{array}$ & luati & $\mathrm{Bu}$ & $\mathrm{Fr}$ & $x$ & $x$ & $x$ & $\begin{array}{l}\text { Edible fruit like gooseberry; presents a pleasant acidic } \\
\text { taste (HNB, p. 80) }\end{array}$ \\
\hline Solanum melongena $\mathrm{L}$. & $\begin{array}{l}\text { Belingela; Macumba; } \\
\text { Tongu }\end{array}$ & $\mathrm{H}$ & $\mathrm{Fr}$ & Cooked & $x$ & $x$ & $\begin{array}{l}\text { This fruit is baked seasoned with olive oil and pepper } \\
\text { and has the flavour of lemon (HNB, p. 24) }\end{array}$ \\
\hline \multicolumn{8}{|l|}{ Talinaceae } \\
\hline $\begin{array}{l}\text { Talinum paniculatum } \\
\text { (Jacq.) Gaertn. }\end{array}$ & Acetosa & $\mathrm{H}$ & $x$ & Used in salads & $x$ & $x$ & It has a nice acidity; it is used for salads (HNB, p. 23) \\
\hline
\end{tabular}


Table 1 Food species mentioned by Marcgrave in the work Historia Naturalis Brasiliae [36] (Continued)

\begin{tabular}{|c|c|c|c|c|c|c|c|}
\hline Urticaceae & & & & & & & \\
\hline $\begin{array}{l}\text { Cecropia concolor } \\
\text { Willd. }\end{array}$ & Ambaiba & $\operatorname{Tr}$ & $\mathrm{Fr}$ & $x$ & Indians & $x$ & Are taken as teeth and eaten (HNB, p. 91-92) \\
\hline \multicolumn{8}{|l|}{ Xanthorrhoeaceae } \\
\hline Aloe vera (L.) Burm. f. & Caraguata & $\mathrm{H}$ & Le & Cooked & $x$ & $x$ & $\begin{array}{l}\text { The leaf and the caudex, cooked in an underground } \\
\text { oven, are edible, tasting like diacitrum (HNB, p. 38) }\end{array}$ \\
\hline \multicolumn{8}{|l|}{ Ximeniaceae } \\
\hline Ximenia americana $\mathrm{L}$. & Jua umbu & $\operatorname{Tr}$ & $\mathrm{Fr}$ & $x$ & Indians & $x$ & This fruit is edible (HNB, p. 108) \\
\hline \multicolumn{8}{|l|}{ Indeterminada } \\
\hline & $\begin{array}{l}\text { Erva (o autor não } \\
\text { menciona o nome) }\end{array}$ & $\mathrm{H}$ & Le; Fl & $x$ & $\begin{array}{l}\text { Blacks from } \\
\text { Angola }\end{array}$ & $x$ & $\begin{array}{l}\text { The blacks from Angola eat the leaves and flowers } \\
\text { (HNB, p. 19) }\end{array}$ \\
\hline
\end{tabular}

Legend: $\mathrm{H}=$ habit $(\mathrm{H}=$ herb; $\mathrm{Bu}=$ bush; $\mathrm{Tr}=$ tree); $\mathrm{PU}=$ part used $(\mathrm{R}=$ root; $\mathrm{S}=$ seeds; $\mathrm{Fr}=$ fruit; $\mathrm{B}=$ bulb; $\mathrm{Le}=\mathrm{Leave} ; \mathrm{Cu}=$ culm; $\mathrm{Nu}=$ nut; $\mathrm{Br}=$ branches; $\mathrm{Po}=$ potato; $\mathrm{FI}=$ flower); $\mathrm{MC}=$ mode of consumption; $\mathrm{WU}=$ who utilises; $\mathrm{Cl}=$ contraindication; HNB = Historia Naturalis Brasiliae; HNB-M = Historia Naturalis Brasiliae, Marcgrave's book; HNB-P = Historia Naturalis Brasiliae, Piso's book; ${ }^{*}=$ species mentioned by Marcgrave but whose food use was discriminated by Piso; $x=$ without information. 
There are references to the consumption of the potato, bulb, stem, nut, branches and grains. From the botanical point of view, some of these terms could be grouped as variants of the organs: stem, fruit and seeds.

Considering the number of citations for each vegetative/reproductive organ noted by Marcgrave, among the consumed parts of the plant, the fruits were the most cited organ in the book of reference (55 citations), followed by seeds (twelve citations), roots (seven citations), leaves (six citations) and nuts (three citations), and the other parts had one citation each (Table 1).

Regarding the mode of consumption of these food plants, Marcgrave mentions 20 modes of ingestion, listed below according to their citation frequencies in the work: cooked (22 citations); fresh, considering for this term the direct ingestion of fruits, seeds and pulp [22]; grilled (five); wine (five), crude (four) as drink and beverage/juice (three citations each); vinegar, honey, spice, dried and conserve (two citations each); mellow, salad, fried, oil, flower, production of sugar and with sugar and seeds in a dough (one citation each) (Table 1). Notably, in addition to the parts of the plant used, some modes of consumption could also be grouped. Thus, it would be possible to consider as fresh usage types the following variants: raw, dried, mellow, salad and spice.

The modes of consumption are diverse and allow the identification of some relation with the part of the plant used. Taking as an example the use of the fruits of the "umari" (Geoffraea sp. - Fabaceae), the indicated mode of ingestion was cooked (Table 1). It is interesting to note that Marcgrave himself said that the fruit of this plant if "eaten raw is prejudicial to the stomach and causes vomiting; that is why it is cooked and smashed with the core" ([36], p. 121). It is noticeable that for some species, there was an appropriate mode of consumption that would avoid the action of chemical constituents of the plant with harmful effects to health or even that would allow better digestion and/or palatability of the consumed part. Commenting on the flavour of Brazilian fruits, the French botanist Auguste de SaintHilaire also reveals this need to improve the palatability of some species by adopting appropriate modes of consumption. Saint-Hilaire states that throughout the different natural environments of Brazil, a huge quantity of fruits could be eaten with pleasure, provided "some care" was given to them; otherwise, the fruits from Europe would be tastier than the ones from Brazil [50]. Another example related to human health is in the therapeutic indication associated to the consumption of the fruits of the pineapple (Ananas sativus Schult. \& Schult. F. Bromeliaceae), whose fresh ingestion would be "given to the sick" ([36], p. 33). The pineapple is considered a functional and nutritious food, rich in vitamin $\mathrm{C}$, betacarotene (provitamin A), B vitamins and minerals such as potassium, manganese and calcium, in addition to the enzyme bromelain. This fruit has the function of restoring energy, has an antispasmodic effect, is a mild laxative and diuretic and has a moderate antioxidant property [51]. Linked to this therapeutic indication, there is evidence that the fruits represent a rich source of vitamins, minerals and fibre [52,53], which would accelerate the recovery of a patient and/or prevent the establishment of disease. Another aspect related to the consumption of fruits is indicated in the writings of Spix and Martius [54], who, when describing their trip through the backcountry of the state of Bahia, noted the use of the fruits of some plants to refresh them and their thirsty animals.

Regarding the origin/ethnicity of the social actors that Marcgrave indicated as using a certain plant as a food resource, although this information was not present in the comments for all the plants considered by Marcgrave, indigenous and African brazilians were the groups most associated with the use of these plants. In total, 32 citations were registered, referring to six ethnic groups that used the food plants referenced by Marcgrave, with 22 citations of use related to Indians, five to blacks and one citation each for the Portuguese, the "people of Guinea", Ethiopians and Americans (Table 1).

Analysing the historical trajectory of these species according to their indications of consumption by specific ethnic groups, it is noticeable that the introduction of some of these plants to Brazil occurred only through the ethnic groups described by Marcgrave. This pattern was the case of Sesamum orientale L. (Pedaliaceae), in Marcgrave's popular designation "sesame", "gangila" or even "girgilim". Originating from Indonesia, China, India and tropical Africa, the plant has been cultivated in India since $1600 \mathrm{BC}$. African slaves brought their seeds from Africa to the Americas. In line with this history of transportation of "girgilim", Marcgrave identifies the blacks as consumers of the oil extracted from its seeds. Commenting on the culinary uses of this plant, Felippe [55] states that sesame is used for oil production. Sesame oil is a key ingredient in Arabic food and tahini sauce, in addition to its seeds being traditionally used in the preparation of breads, cakes, etc. Regarding the past use of this plant, Felippe [55] states that in Northeast Brazil, at the time of slavery, a toasted sesame flour mixture had a widespread use.

"Perexil" (Iresine vermicularis (L.) Moq.) also has an indication of consumption in concordance with the ethnic group that was responsible for its introduction to Brazilian lands. Regarding the use of this plant food, Marcgrave states that "the leaves and branches cut short and boiled with a little vinegar can be spiced and preserved as a pickle, to be eaten with meat and fish. It has a great flavour and is highly valued by the Portuguese" ([36], p. 14). Henriquez, physician to King John V of 
Portugal (1689-1750) states in his treatise that "in order to conserve a healthy life", "perexil" was eaten as a condiment in Portugal [56].

Marcgrave, commenting on the consumption of the root of the yam or "yam of São Tomé" (Polynome alata (L.) Salisb.), states that it was a food that replaced bread for the "inhabitants of Guinea". Combining this information with the consumption data of this plant presented by Felippe [55], processed tuberous roots were one of the foods most appreciated by the blacks from West Africa. The yam is a plant from Vietnam, which had a wide distribution in prehistoric times, including other species of the genus [55].

Based on an analysis of each ethnic group and the parts and mode of ingestion of food plants, Indians notably account for the majority of consumption of fruits (16 citations) eaten fresh and/or "mellow" (five citations); as spice, juice, wine or conserve (with a citation each); or with an unspecified mode of consumption (seven citations). Among the fruits consumed fresh, examples include the pineapple, the pepper (Capsicum annuum var frutescens (L.) Kuntze - Solanaceae) and "inga" (Inga vera Willd. - Fabaceae). The mode of consumption could be a way that the Indians found to minimise or even remove the toxic effects present in some of the species consumed. However, it was not possible to establish a relation between the part of the plant and its mode of consumption. Regarding other ethnic groups, it was not possible to trace a tendency of preference. But, according to the concise narrative of Marcgrave it is possible to assert that the blacks consumed a large variety of plant parts, such as the root, leaves, flowers, fruits and seeds. The author points the use of "meeru" (Canna indica L. Cannaceae), where Marcgrave says that "the blacks eat the root" (HNB, p. 4) (see Table 1). For "pindoba" (Attalea oleifera Barb. Rodr. - Arecaceae) and "sésamo" (S.orientale), there is a more detailed report, that is that these species were consumed by the blacks as a pulp, eaten with flour and as an oil "extracted from the seed, and residuals eaten with corn" ([36], p. 133-134; p. 21).

\section{Considerations of the use of Marcgravian species today}

By analysing the knowledge/use of species mentioned by Marcgrave over time, a relation between historical and current uses may be observed. For some plants, such as the "umbu" (Spondias tuberosa Arruda) and "pitomba" (Talisia esculenta (St. Hill.) Radlk.), the knowledge/recorded usage in the 17th century source was maintained over the centuries in the northeast region of Brazil $[13,57,58]$. Other species are also currently consumed in other regions of the country and in various regions of the world. This pattern was the case of plants such as guava (Psidium guajava L.) and papaya (Carica papaya L.), which have a wide geographical distribution and are traded in the international market of food products $[55,59]$. Rich in vitamins $B$ and $C$, the guava is a plant that originated in tropical America, southern Central America and northern South America [60]. The earliest evidence of guava cultivation in Mexico dates from the beginning of the Christian era. The introduction of guava to Brazil occurred before the colonial discovery, and the Portuguese took it to their other colonies [55]. The papaya originated from Panama and the northwest coast of Colombia and was taken to Malaysia, the Philippines and other countries of the East between the 1600s and 1700s. The latex, seeds, leaves, stem bark and green fruits of papaya contain papain, a proteolytic enzyme used for the digestion of meat. The fruits are rich in vitamin $\mathrm{C}$ and $\mathrm{A}$ and are currently consumed fresh and as juice, ice cream, jelly and candied fruit [55,60].

Some species deserve special attention because they are endemic plants of the Caatinga region, comprising the Brazilian semiarid region. This group includes the aforementioned "umbu", the "mandacaru" (Cereus jamacaru DC.) and the "carnauba" (Copernicia cerifera Mart.).

"Umbu" has been reported over time as a central species for feeding the local population. In addition to Marcgrave, other naturalists also recorded its food usage even before their passage through the region, such as Gabriel Soares de Sousa in 1587 [61] and also after the period that he spent in Brazil in the 19th century, as can be seen in George Gardner's writings in 1846 [62] and Philipp von Martius's in 1844 [63]. Papers published in the mid-20th and early 21 st century also indicate the current consumption of the fruits of this plant, mainly fresh $[13,57,58,64,65]$. Another mode of preparation for the consumption of fruits, considered characteristic of the backlanders (sertanejos), was referenced by Martius [63]: the food traditionally called "umbuzada", classified by the naturalist as a healthy and refreshing food. Currently, the consumption of "umbu" fruits is diverse, in the form of beverages, ice cream, jams, jellies, vinegars, wine and liquor [57]. Moreover, salads are also prepared with the green or fresh leaves of the plant, and edible flour is produced using its root [57]. The backlanders also uses the root to relieve thirst and hunger, consuming the root in the same way as they would sugarcane [66]. Within this vegetable organ, studies have found the presence of protein, crude fibre, ether extract, tannin, starch, sulphur, phosphorous, calcium and magnesium $[67,68]$.

With an equal food indication, "mandacaru" is mentioned by Marcgrave and Andrade-Lima [64], who describe the consumption of fresh fruits. Evaluating the physicochemical properties of the fruits of this species, studies indicate the potential for exploitation in industry and biotechnological processes, including alcoholic and acetic fermentation and the production of distilled drinks $[69,70]$. 
For "carnauba", in addition to Marcgrave, Arruda Câmara [71] and Braga [66] commented on the ingestion of "carnauba" root as a condiment and of the fruits, nuts and heart of palm in a fresh form. However, for this species, there are no current studies addressing the issue of nutritional potential.

The list of food plants presented by Marcgrave was represented in 18 ethnobotanical studies conducted in Northeast Brazil (Table 2). In these works, there was information pertaining to 33 species with food uses in the referenced primary source (28\% of the total species). However, for this group of plants, the data from current research were not restricted to food usage, with indications of use in other categories such as medical use, fence construction, shade and forage production (see, e.g., 13 and 72). Concentrating the analysis only on species indicated for consumption today, there is a reduction in the number of food plants to 11 (see Table 2). Thus, for example, it can be asserted that the use of species such as Anacardium occidentale L., Crateva tapia L., Manihot glaziovii Müll. Arg., P. guajava, S. tuberosa and T. esculenta were perpetuated over the centuries through the habits of the population of the northeast region of Brazil $[13,16,72,79-93]$.

The part of the plant ingested is not specified in much of the current research. However, for S. tuberose, there is only mention of the consumption of the fruit and root of this plant [13]. In Historia Naturalis Brasiliae, however, Marcgrave states that in addition to these organs, the leaves of "umbu" were used in a beverage (Table 1).

How can one justify the small number of plants with indications of current food use in relation to the total list of Marcgravian food species?

Two factors may have been crucial to generate this scenario: the focus of the analysed research was not exclusively to record the food use of plant species, and works with different approaches were included because few studies were dedicated solely to food plants; additionally, there may be weaknesses in the methodology of works devoted to the investigation of food plants.

It would be possible to also consider a historical view of the dynamics of knowledge and/or use of plant species in human cultural practice. From this perspective, the food use of a plant would serve as a starting point for the species to be integrated into the local culture. As part of the diet, this plant would be subsequently and gradually included in other categories of use, and new applications would go through cultural fixation with the passing of time. In this process, the act of feeding upon this plant would lose its importance, and the food use would no longer be a habit remembered and transmitted among the members of a given human community. This hypothesis may be reinforced by the fact that a high percentage of Marcgravian species are used today in categories other than food (Table 2).

Among these categories of current use, the medicinal category stands out (32 species) (Table 2). In a study discussing the ways by which exotic species enter the knowledge and practices of local populations, it is stated that these species are used for various purposes, such as for food and ornamentation [73]. This study proposes the idea of versatility, which has been assumed as a hypothesis by other authors [74], asserting that medicinal use would not be the reason for a species' introduction into a given culture; rather, the therapeutic use would develop in a second phase. An exotic species with greater versatility has a greater likelihood of inclusion within cultural habits and subsequent medicinal use. Contemplating this scenario presented by the versatility hypothesis and the presence of 17th century plants listed in the contemporary literature primarily for medicinal use, it is suggested that food use has functioned as a "gateway" for plant resources (native and/or exotic) into the culture of the northeast region of Brazil. Thus, the food species described by Marcgrave would have been incorporated by the local pharmacopoeias over time. In a broader analysis of Brazilian culture, it is possible to consider that certain species may have become medicinal plants and ceased to be recognised as food due to the commonly present attitude among the Brazilian population of not considering food as good for health but seeking cures for illnesses through medicines. In this case, the transition from the food category to the medicine category would be explained by this mentality of giving little importance to food as preventive medicine. Only in recent years has this situation begun to change through the dissemination by the media of the idea that a balanced diet is associated with individual good health and wellbeing.

It must also be considered that local populations, particularly those settled in the northeast region of Brazil, began to associate certain plants with periods of food scarcity. It is common for local populations to consider the consumption of species that entered the diet in extreme periods of food shortage shameful [75]. For local populations throughout Latin America, this attitude of considering the ingestion of these plants a sign of poverty is present [76,77]. This attitude may help to elucidate the process of the use/disuse of plant species as food sources. The cultural taboo associated with a plant food would then be an imperative factor in the restriction and/or gradual discontinuation of the use of certain resources. Cultural taboos become decisive in the erosion process of local knowledge because certain "knowledge" and "practices" become unprivileged information during the oral transmission of knowledge and cultural practices, a mode of transmission commonly exercised 
Table 2 Marcgravian edible species mentioned in ethnobotanical studies conducted in the northeast region of Brazi

\begin{tabular}{|c|c|c|c|}
\hline Taxonomic track & Popular name (Local) & Use category (PU) & Reference \\
\hline \multicolumn{4}{|l|}{ Anacardiaceae } \\
\hline Anacardium occidentale L. & $\begin{array}{l}\text { Caju-roxo, Caju-branco, Cajú, Cajueiro } \\
\text { (RNE - PE, PB, CE) }\end{array}$ & $\begin{array}{l}\text { Fo, Med (Bar, Le), Woo, Fue, } \\
\text { Cons, Tec, FC, SP }\end{array}$ & [79-91] \\
\hline Schinus terebinthifolius Raddi & Aroeira (RNE) & Med (Bar), Woo, Fue, Cons, Tec & {$[79,82,90]$} \\
\hline Spondias purpurea $\mathrm{L}$. & Seriguela, Siriguela (RNE - PE, CE) & Fo, Med (Bar, Le), Woo, FC & {$[72,79,81,82,85,86]$} \\
\hline Spondias tuberosa Arruda & $\begin{array}{l}\text { Imbu, Umbu, Umbú, Umbuzeiro } \\
\text { (RNE - PE, PB) }\end{array}$ & $\begin{array}{l}\text { Fo (Fr, R), Med (Bar, Le, Fr, R, Re), } \\
\text { For, Woo, Fue, SP }\end{array}$ & {$[13,72,79-81,83-85,87,89,92]$} \\
\hline \multicolumn{4}{|l|}{ Annonaceae } \\
\hline Xylopia frutescens Aubl. & Imbira-vermelha (PE) & Woo, Fue, Cons, Tec & {$[82,90]$} \\
\hline \multicolumn{4}{|l|}{ Arecaceae } \\
\hline Cocos nucifera L. & Coco (RNE - PE) & $\begin{array}{l}\text { Fo, Med (En), Woo, Cons, Tec, } \\
\text { FC, Orn, SP }\end{array}$ & {$[72,79,81,82,85,86,90]$} \\
\hline Syagrus coronata (Mart.) Becc. & Licurizeiro (RNE) & $\operatorname{Med}(\mathrm{Fl}, \mathrm{Fr})$ & [79] \\
\hline \multicolumn{4}{|l|}{ Bignoniaceae } \\
\hline Crescentia cujete L. & Coité (RNE - PE) & Med (Le, S) & {$[79,91]$} \\
\hline \multicolumn{4}{|l|}{ Bixaceae } \\
\hline Bixa orellana $\mathrm{L}$. & Urucum (RNE - CE) & Med (Le, Fr, S) & {$[79,88]$} \\
\hline \multicolumn{4}{|l|}{ Bromeliaceae } \\
\hline Ananas sativus Schult. \& Schult. f. & Abacaxi (RNE - PE, CE) & Med (Fr) & {$[79,81,88,89]$} \\
\hline \multicolumn{4}{|l|}{ Cactaceae } \\
\hline Cereus jamacaru D.C. & $\begin{array}{l}\text { Mandacaru, Mandacarú, Babão, Cardeiro } \\
\text { (RNE - PE, CE) }\end{array}$ & Fo $(P, S) ; \operatorname{Med}(C l a, F r, R)$ & {$[15,79-81,83,85,88,91]$} \\
\hline \multicolumn{4}{|l|}{ Cannaceae } \\
\hline Canna indica $\mathrm{L}$. & Cana-da-índia (RNE) & Med & [79] \\
\hline \multicolumn{4}{|l|}{ Capparaceae } \\
\hline Crataeva tapia $\mathrm{L}$. & Trapiá (RNE - PE) & $\begin{array}{l}\text { Fo, Med (Bar, Le, Fr, R), Fue, } \\
\text { Cons, Tec, For, SP }\end{array}$ & {$[72,79,84,91,93]$} \\
\hline \multicolumn{4}{|l|}{ Caricaceae } \\
\hline Carica papaya L. & $\begin{array}{l}\text { Mamão, Mamoeiro, Papaya, } \\
\text { Mamão de corda (RNE - PE, CE) }\end{array}$ & Med (Fl, Le, Fr, La), Woo, FC & {$[79-82,85,86,88]$} \\
\hline \multicolumn{4}{|l|}{ Convolvulaceae } \\
\hline Ipomoea batatas (L.) Lam. & Batata-doce (CE, PE) & Med (Le) & {$[80,85,88]$} \\
\hline \multicolumn{4}{|l|}{ Cucurbitaceae } \\
\hline Cucurbita pepo L. & Jerimum, Abóbora (RNE) & Med (S) & {$[79,81]$} \\
\hline Citrullus lanatus (Thunb.) Matsum. \& Nakai & Melancia (PE) & Med & [85] \\
\hline \multicolumn{4}{|l|}{ Euphorbiaceae } \\
\hline Manihot esculenta Crantz & Mandioca (RNE - PE, CE) & Med (Le, La, R) & {$[79,88,89]$} \\
\hline Manihot glaziovii Müll. Arg. & Maniçoba (RNE) & Fo (R), Med (Fl, Le) & {$[16,79]$} \\
\hline \multicolumn{4}{|l|}{ Fabaceae } \\
\hline Cajanus cajan (L.) Huth & Feijão guandu, Feijão guandu (PE) & Med (S) & {$[80,81,91]$} \\
\hline Lablab purpureus (L.) Sweet & Feijão cabricuço (PE) & Med (S) & [91] \\
\hline \multicolumn{4}{|l|}{ Malvaceae } \\
\hline Hibiscus esculentus L. & Okra (PE) & $\operatorname{Med}(F r, S)$ & [91] \\
\hline \multicolumn{4}{|l|}{ Musaceae } \\
\hline Musa paradisiaca $\mathrm{L}$. & Banana-prata, Banana (RNE - PE, CE) & Fo, Med (Le, Fl, Fr, R) & {$[72,79-81,85,88,89]$} \\
\hline \multicolumn{4}{|l|}{ Myrtaceae } \\
\hline Eugenia uniflora $\mathrm{L}$. & Pitanga (RNE - PE) & Fo, Med (Le), Woo & {$[72,79-82,85]$} \\
\hline Psidium guajava $\mathrm{L}$. & $\begin{array}{l}\text { Goiaba, Goiabeira, Goiaba branca } \\
\text { (RNE - PE), Goiaba vermelha (CE) }\end{array}$ & $\begin{array}{l}\text { Fo, Med (Le, Fl, R), Woo, Fue, } \\
\text { Cons, Tec, SP }\end{array}$ & {$[72,79-83,85,88-90]$} \\
\hline
\end{tabular}


Table 2 Marcgravian edible species mentioned in ethnobotanical studies conducted in the northeast region of Brazil (Continued)

\begin{tabular}{|c|c|c|c|}
\hline Passifloraceae & & & \\
\hline Passiflora cincinnata Mast. & Maracujá-do-mato (CE) & Med (Le) & [88] \\
\hline \multicolumn{4}{|l|}{ Pedaliaceae } \\
\hline Sesamum orientale L. & Sesame, Gergelim-branco (RNE - PE) & Med (S) & {$[79,91]$} \\
\hline \multicolumn{4}{|l|}{ Piperaceae } \\
\hline Piper marginatum Jacq. & Capeba (RNE - PE) & Med (Le) & {$[79,91]$} \\
\hline \multicolumn{4}{|l|}{ Portulacaceae } \\
\hline Portulaca oleracea $\mathrm{L}$. & $\begin{array}{l}\text { Beldroega-branca, Bedroégua } \\
\text { (RNE - PE) }\end{array}$ & Med (Le, AP), For & {$[79,92]$} \\
\hline \multicolumn{4}{|l|}{ Rubiaceae } \\
\hline Genipa americana L. & Genipapo (RNE - PE, CE) & Med (Bar, Fr), Tec & {$[79-81,88,90,91]$} \\
\hline \multicolumn{4}{|l|}{ Sapindaceae } \\
\hline Talisia esculenta (A. St.-Hil.) Radlk. & Pitomba (PE) & $\begin{array}{l}\text { Fo, Med (Bar), Woo, Fue, Cons, } \\
\text { Tec, FC, SP }\end{array}$ & {$[72,80-82,84-86,90,91]$} \\
\hline \multicolumn{4}{|l|}{ Solanaceae } \\
\hline Solanum agrarium Sendtn. & Melancia-da-praia, Gogóia (RNE) & Med (WP, R) & [79] \\
\hline \multicolumn{4}{|l|}{ Xanthorrhoeaceae } \\
\hline Aloe vera (L.) Burm. f. & Babosa, Erva-babosa (PE) & Med & [89] \\
\hline
\end{tabular}

in human cultures [78]. As a result of this disruption, the knowledge lacks subsequent perpetuation among generations of local populations.

In the quest to understand the complex processes of the arrival, fixing and/or deletion of food plants in the diet of the human population of a particular place, it is essential to refer to the story. Historical analysis serves as a facilitating approach to unravel Brazil's multicultural diet, translating and identifying peoples, cultures and eating habits that were enriched and adapted during the development of the country.

\section{Conclusions}

In his treatise Historia Naturalis Brasiliae, Marcgrave mentions a diverse cast of food plants, mainly of arboreal habit. In a thorough manner, the characteristics of each species are revealed along with what they represented for Indians, Africans and Portuguese - the ethnic groups who held the knowledge of their use.

Despite the continued presence of the food species described by Marcgrave in the regional food habit, and even on a global scale, there has been a lack of studies of some species endemic to the Caatinga for exploitation in biotechnological processes and agro-industry. There is, therefore, a pressing need to devote efforts to deepen the knowledge and use of food species native to this region. The great nutritional and productive potential of these species have been undervalued, losing the opportunity to meet the demand for local consumption and even the demands of the global market that could exist if emphasis was given to the study of these species. Useful future research could be conducted considering species such as $C$. jamacaru and C. cerifera.

The analysis presented here allows a transfer of information about species used for food from the past to the present. It is hoped that future studies promote a change in the specialised dietary patterns of today, based on the research presented here. Finally, a means of food diversification, accessible to local populations, may be achieved through the use of this information for the development of new food products.

\section{Competing interests}

The authors declare that they have no competing interests.

\section{Authors' contributions}

UPA and MFTM contributed to the design of the study, interpretation of the findings and preparation of the manuscript. Both authors read and approved the final manuscript.

\section{Acknowledgements}

To CNPq (National Council for Scientific and Technological Development) for the research support and postdoctoral scholarships granted to U.P. Albuquerque and M.F.T. Medeiros, respectively. This paper is contribution P016 of the Rede de Investigação em Biodiversidade e Saberes Locais (REBISA-Network of Research in Biodiversity and Local Knowledge), with financial support from FACEPE (Foundation for Support of Science and Technology) to the project Núcleo de Pesquisa em Ecologia, conservação e Potencial de Uso de Recursos Biológicos no Semiárido do Nordeste do Brasil (Center for Research in Ecology, Conservation and Potential Use of Biological Resources in the Semi-Arid Region of Northeastern Brazil-APQ-1264-2.05/10). 


\section{Author details}

${ }^{1}$ Universidade Federal de Campina Grande, Campus de Cuité, Centro de Educação e Saúde, Unidade Acadêmica de Educação, Departamento de Ciências Biológicas, Olho D’Água da Bica s/n, Cuité, Paraíba CEP: 58175-000, Brazil. ${ }^{2}$ Laboratory of Applied and Theoretical Ethnobiology (LEA), Department of Biology, Area of Botany, Federal Rural University of Pernambuco, Av. Dom Manoel de Medeiros s/n, Dois Irmãos, Recife, Pernambuco CEP: 52171-900, Brazil.

Received: 6 March 2014 Accepted: 14 June 2014

Published: 25 June 2014

\section{References}

1. Eyssartier C, Ladio AH, Lozada M: Cultural transmission of traditional knowledge in two populations of North-western Patagonia. J Ethnobiol Ethnomed 2008, 4:25.

2. Ladio AH: The maintenance of wild edible plant gathering in a mapuche community of Patagonia. Econ Bot 2001, 55(2):243-254.

3. Ladio AH, Lozada M: Edible wild plant use in a Mapuche community of Northwestern Patagonia. Hum Ecol 2000, 28(1):53-71.

4. Ladio AH, Lozada M: Comparison of wild edible plant diversity and foraging strategies in two aboriginal communities of northwestern Patagonia. Biodivers Conserv 2003, 12:937-951.

5. Ladio AH, Lozada M: Patterns of use and knowledge of wild edible plants from distinct ecological environments: a case study of a Mapuche community from NW Patagonia. Biodivers Conserv 2004, 13(6):1153-1173.

6. Ladio AH, Lozada M: Comparison of traditional wild plants use between two Mapuche communities inhabiting arid and forest environments in Patagonia, Argentina. J Arid Environ 2007, 69:695-715.

7. Lozada M, Ladio AH, Weigandt M: Cultural transmission of ethnobotanical knowledge in a rural community of Northwestern Patagonia. Argent Eco Botany 2006, 60(4):374-385.

8. Toledo BA, Galetto L, Colantonio S: Ethnobotanical knowledge in rural communities of Cordoba (Argentina): the importance of cultural and biogeographical factors. J Ethnobiol Ethnomed 2009, 5:40.

9. Amorozo MCM: Maintenance and management of agrobiodiversity in small-scale agriculture. Funct Ecosystems Communities 2008, 2:11-20.

10. Salgado $\mathrm{CL}$, Guido $\mathrm{E}: \mathrm{O}$ conhecimento popular sobre plantas: um estudo etnobotânico em quintais do distrito de Martinésia, Uberlândia, MG [The popular knowledge about plants: an ethnobotanical study of the gardens in the district of Martinésia, Uberlândia, MG.]. In IV ENANPPAS, Encontro Nacional da Anppas [IV ENANPPAS, ANPPAS National Meeting]. 2008 [http://www.anppas.org.br]

11. Chaves EMF, Barros RFM: Plantas de uso alimentício no semi-árido Piauiense, Nordeste, Brasil [Plants for food use in the Piauí semi-arid region, Northeast Brazil]. In Sustentabilidade do semi-árido [Sustainability of semi-arid regions]. Edited by Lopes WGR, Monteiro MSL, Moita NJM. Teresina: EDUFPI; 2009.

12. Pilla MAC, Amorozo MCM: O conhecimento sobre os recursos vegetais alimentares em bairros rurais no Vale do Paraíba, SP, Brasil [Knowledge regarding vegetable food resources in rural neighbourhoods in the Paraíba Valley, São Paulo state, Brazil]. Acta Bot Bras 2009, 23(4):1190-1201.

13. Lins Neto EMF, Peroni N, Albuquerque UP: Traditional knowledge and management of Umbu (Spondias tuberosa, Anacardiaceae): an endemic species from the Semi Arid Region of Northeastern Brazil. Econ Bot 2010, 64:11-21.

14. Lins Neto EMF, Peroni N, Maranhão CMC, Maciel MIS, Albuquerque UP: Analysis of umbu (Spondias tuberosa Arruda (Anacardiaceae)) in different landscape management regimes. a process of incipient domestication? Environ Monit Assess 2012, 184(7):4489-4499. doi.org/ 10.1007/s|10661-011-2280-7.

15. Nascimento VT, Moura NP, Vasconcelos MAS, Maciel MIS, Albuquerque UP: Chemical characterization of native wild plants of dry seasonal forests of the semi-arid region of northeastern Brazil. Food Res Int 2011, 44:2112-2119.

16. Nascimento VT, Vasconcelos MAS, Maciel MIS, Albuquerque UP: Famine foods of Brazil's seasonal dry forests: ethnobotanical and nutritional aspects. Econ Bot 2012, 66:22-34

17. Cunha E: Os Sertões: Campanha de Canudos [Rebellion in the Backlands: The Canudos Campaign]. Rio de Janeiro: Laemmert; 1902.

18. Castro J, Pechnick E, Parahim O: Os alimentos barbarous dos sertões do Nordeste [Barbarous foods of the Northeast backlands]. Arquivos Brasileiros Nutrição 1946, 3(2):5-29.
19. Castro J: Geografia da fome [Geography of Hunger]. São Paulo: Editora Brasiliense; 1967.

20. Nascimento VT: Estudo comparativo de plantas alimentícias em comunidades rurais da caatinga pernambucana e paraibana: etnobotânica, potencial econômico e conteúdo nutricional [Comparative study of food plants in rural communities of Pernambuco and Paraiba caatinga: ethnobotany, economic potential and nutritional content]. Universidade Federal Rural de Pernambuco, Pró-Reitoria de Pesquisa e Pós-Graduação: PhD thesis; 2010.

21. Hughes J: Just famine foods? What contributions can underutilized plants make to food security? Acta Horticult 2009, 806:39-47.

22. Ellen R: Traditional environmental knowledge in island Southeast Asia: some consequences of its demise and re-discovery for local coping strategies. In Modern crises and traditional strategies: local ecological knowledge in island southeast Asia. Edited by Ellen R. Oxford: Berghan; 2007:1-45.

23. Piso W, Marcgrave G: In Historia Naturalis Brasiliae: in qua non tantum plantæ et animalia, sed et indigenarum morbi, ingenia et mores describuntur et iconibus supra quingentas illustrantur. Edited by de Laet J. Amsterdam: Elzevier; 1648. http://biblio.etnolinguistica.org/marcgrave-1648-historia.

24. Hoehne FC: Botânica e agricultura no Brasil no século XVI [Botany and agriculture in Brazil in the 16th century]. São Paulo: Companhia Editora Nacional; 1937.

25. Moreira J: Os iniciadores do estudo da Medicina e da História Natural no Brasil (W. Pies e G. Marcgrave) [The initiators of the study of Medicine and Natural History in Brazil (W. Pies and G. Marcgrave)]. Instituto Histórico e Geográfico Brasileiro [Brazilian Geographical and Historical Institute]. Rio de Janeiro: Imprensa Nacional; 1917.

26. Martius CFP V, Eichler AW, Urban IU: Flora brasiliensis. Alemanha: Monachii et Lipsiae; 1840. 1906.

27. Boxer CR: Os holandeses no Brasil: 1624-1654 [Dutchmen in Brazil: 1624-1654]. Recife: CEPE; 2004

28. Mello EC (Org.): O Brasil holandês (1630-1654) [The Dutch Brazil (1630-1654)]. São Paulo: Penguin Classics and Companhia das Letras; 2010.

29. Gesteira HM: O teatro das coisas naturais: conhecimento e dominação neerlandesas no Brasil (1624-1654) [The theater of natural things: knowledge and Dutch rule in Brazil (1624-1654)]. $169 \mathrm{f}$. Universidade Federal Fluminense: PhD thesis; 2001

30. Avancini EG: Doce inferno: açúcar, guerra e escravidão no Brasil holandês, 1580-1654 [Sweet hell: sugar, war and slavery in Dutch Brazil, 1580-1654]. São Paulo: Atual; 1991.

31. Gesteira HM: O Recife Holandês: História Natural e Colonização Neerlandesa (1624-1654) [The Dutch Reef: Dutch Natural History and Colonization (1624-1654)]. Revista Sociedade Brasileira de História Ciência 2004, 2(1):6-21.

32. Françoso MC: De Olinda a Olanda: Johan Maurits van Nassau e a circulação de objetos e saberes no Atlântico holandês (século XVII) [From Olinda to Oland: Johan Maurits van Nassau and movement of objects and knowledge in the Dutch Atlantic (17th century)]. Universidade Estadual de Campinas, Instituto de Filosofia e Ciências Humanas: PhD thesis; 2009.

33. Leite JRT: A pintura no Brasil holandês [Painting in Dutch Brazil]. Rio de Janeiro: GRD; 1967

34. Lichtesnstein H: Estudo critico dos trabalhos de Marcgrave e Piso sobre a história natural do Brasil à luz dos desenhos originais. [Critic study of Marcgrave's and Piso's work on the natural history of Brazil in the light of the original drawings] [S.I.: s.n.]. 1961.

35. Pickel Dom BJ: Piso e Marcgrave na Botânica Brasileira. Para o tricentenário de sua chegada ao Brasil [Piso and Marcgrave in Brazilian Botany. For the tercentenary of his arrival in Brazil. Revista Flora Med 1949, 16(5):155-199.

36. Marcgrave G: História Natural do Brasil [Natural History of Brazil]. São Paulo: Imprensa Oficial do Estado; 1942 [1648].

37. Laet J: Roteiro de um Brasil desconhecido: descrição das costas do Brasil [Guide of an unknown Brazil: description of the coasts of Brazil]. José Paulo Monteiro \& Cristina Ferrão (Organization). Petrópolis: Kapa; 2007.

38. Anónimo: Atlas de las costas y de las posesiones portuquesas en América y Africa, S. XVII. Madrid: Biblioteca Nacional de Madrid.

39. Aublet MF: Histoire des plantes de la Guiane Françoise [History of the plants of French Guiane]. London and Paris: Pierre Fr. Didot; 1775.

40. Lineu C: Species Plantarum uno volumine: edition critica adstricta, conferta, sive, Codex Botanicus Linnaeanus. Lipsiae: sumptum fecit O. Wigard; 1840.

41. Martius CF V: Versuch eines kommentars ueber die Pflanzen in den werken von Markgrav und Piso ueber Brasilien nebst weiteren 
Eroerterungen ueber die Flora dieses Reiches. Abnandl. Kgl. Akad. Wissenschaften Math-Phys Klasse 1855, 7(1):179-238.

42. Pio Correa P: Dicionário das plantas úteis do Brasil e das exóticas cultivadas [Dictionary of useful plants of Brazil and exotic cultivated ones]. Rio de Janeiro: Imprensa Nacional; 1926.

43. Piso W: De Indiae utriusque re Naturali et Medica libri quattuordecim. Amsterdam: Elzevier; 1658.

44. Medeiros MFT: Procedimentos para a análise documental na constituição da informação etnobiológica [Procedures for document analysis in the constitution of ethnobiological information]. In Métodos e técnicas na pesquisa etnobiológica e etnoecológica [Methods and techniques in ethnobiological and ethnoecological research]. Edited by Albuquerque UP, Lucena RFP, Cunha LVFC. Recife: NUPEEA; 2010:419-436.

45. Pickel Dom BJ: Flora do Nordeste do Brasil segundo Piso e Marcgrave no século XVII [Flora of Northeast of Brazil according to Piso and Marcgrave in the 17th Century]. Recife: EDUFRPE; 2008.

46. Missouri Botanical Garden's VAST (VAScular Tropicos) Nomenclatural Database W3 Tropicos. http://mobot.mobot.org/W3T/Search/vast.html.

47. The International Plant Names Index - IPNI. http://www.ipni.org/ipni/ plantnamesearchpage.do.

48. Judd WS, Campbell CS, Kellogg EA, Stevens PF: Sistemática vegetal: um enfoque filogenético [Plant Systematics: A Phylogenetic Approach]. Porto Alegre: Artmed; 2009.

49. Stuessy TF: Plant Taxonomy: The Systematic Evaluation of Comparative Data. New York: Columbia University Press; 2009

50. Saint-Hilaire A: Plantes usuelles des brésiliens [Usual Brazilian plants]. Paris: Grimbert Libraire: 1824

51. United States Department of Agriculture (USDA). http://www.ars.usda.gov/ services/docs.htm.

52. Bruce JW: Seguridad alimentaria familiar y silvicultura [Household food security and forestry]. http://www.fao.org.

53. Melo EA, Maciel MIS, Lima VLAG, Nascimento RJ: Capacidade antioxidante de frutas [Antioxidant capacity of the fruit]. Revista Brasileira Ciências Farmacêuticas 2008, 44(2):193-201.

54. Spix JB, Martius KFP: Viagem pelo Brasil (1817-1820) [Trip through Brazil (1817-1820)]. São Paulo: Edusp/Itatiaia; 1981.

55. Felippe G: O saber do sabor: as plantas nossas de cada dia [The Knowledge of Flavour: Our Everyday Plants]. São Paulo: Edições Salamandra; 1998.

56. Henriquez FF: Âncora medicinal: para conservar a vida com saúde [Medicinal Anchor: to Preserve Life with Health]. Cotia: Ateliê Editorial; 2004.

57. Maia GN: Caatinga: árvores e arbustos e suas utilidades [Caatinga: trees and bushes and their uses]. São Paulo: Dandz Computação Gráfica e Editora; 2004.

58. Ferraz JSF, Meunier IMJ, Albuquerque UP: Conhecimento sobre Espécies Lenhosas Úteis da Mata Ciliar do Riacho do Navio, Floresta, Pernambuco [Knowledge about Useful Woody Species of the Riparian Forest of Riacho do Navio, Floresta, Pernambuco]. Zonas Áridas 2005, 9:27-39.

59. Silva S, Tassara H: Frutas no Brasil [Fruits in Brazil]. São Paulo: Nobel; 2001.

60. Cavalcanti MLM: História dos sabores pernambucanos [History of Pernambuco flavours]. Recife: Fundação Gilberto Freyre; 2010.

61. Souza GS: Tratado descritivo do Brasil em 1587 [Descriptive treatise of Brazil in 1587]. São Paulo: Cia. Ed. Nacional; EDUSP (Collection Brasiliana, vol 117 Original from 1587); 1971.

62. Gardner G: Contributions towards a Flora of Brasil, being the characters of several new species of compositae, belonging to the tribe Euphorbiaceae. Lond J Bot 1846, 1846:455-491.

63. von Martius CFP: Natureza, doenças, medicina e remédios dos índios brasileiros (1844) [Nature, diseases, medicine and remedies of Brazilian Indians (1844)]. São Paulo: Nacional; 1979

64. Andrade-Lima D: Contribution to the Study of the Flora of Pernambuco, Brazil. Monograph I. Recife: Universidade Federal Rural de Pernambuco; 1954.

65. César G: Curiosidades da nossa flora [Curiosities of our flora]. Recife: Imprensa Oficial de Recife; 1956.

66. Braga R: Plantas do Nordeste: especialmente do Ceará [Plants of the Northeast: Especially Ceará]. Natal: ESAM; 1976.

67. Cavalcanti NB, Resende GM, Brito LTL: Desenvolvimento do Umbuzeiro (Spondias tuberosa Arruda.) na Região Semiárida do Nordeste Brasileiro [Development of Imbu trees (Spondias tuberosa Arruda) in the Semi-Arid Region of Northeast Brazil]. Ciência Agrotécnica 1999, 23(1):212-213.

68. Cavalcanti NB, Resende GM, Brito LTL: Extrativismo vegetal como fator de absorção de mão- de-obra e geração de renda: o caso do imbuzeiro
(Spondias tuberosa Arruda.) [Plant extraction as a factor of absorption of skilled labour and income generation: the case of imbuzeiro (Spondias tuberosa Arruda)]. In XXXVII Congresso brasileiro de economia e sociologia rural [XXXVII Brazilian Congress of economy and rural sociology. Sociedade Brasileira de Economia, Administração e Sociologia Rural: Foz do Iguaçú; 1999b.

69. Oliveira FMN, Figueirêdo RMF, Queiroz AJM, Almeida CA: Caracterização fisíco-quimica das polpas dos ramos do mandacaru [Physical-chemical characterization of the pulps and branches of mandacaru]. Revista Brasileira de Produtos Agroindustriais 2007, 11(1):15-20.

70. Almeida MM, Silva FLH, Conrado LS, Freire RMM, Valença AR: Caracterização Física e físico-química de frutos do mandacaru [Physical and physical-chemical characterization of the mandacaru fruits]. Revista Ciên Agron 2007, 38(4):440-443.

71. Câmara MA: Manuel Arruda da Câmara: obras reunidas [Manuel Arruda da Câmara: Collected Works]. Recife: Fundação de Cultura Cidade do Recife; 1982

72. Florentino ATN, Araújo EL, Albuquerque UP: Contribuição de quintais agroflorestais a conservação de plantas da Caatinga, Município de Caruaru, PE, Brasil [Contribution of home gardens to the conservation of caatinga plants, Municipality of Caruaru, Pernambuco State, Brazil]. Acto Bot Bras 2007, 21(1):37-47.

73. Bennett BC, Prance GT: Introduced plants in the indigenous pharmacopeia of northern South America. Econ Bot 2000, 54(1):90-102.

74. Alencar NL, Araújo TAS, Amorim ELC, Albuquerque UP: The inclusion and selection of medicinal plants in traditional pharmacopoeias-evidence in support of the diversification hypothesis. Econ Bot 2010, 64(1):68-79.

75. Guinand Y, Lemessa D: Wild-food plants in Ethiopia: Reflections on the role of wild foods and famine foods at a time of drought. In The Potential of Indigenous Wild Foods. Edited by Kenyatta C, Henderson A. USA/Southern Sudan: OFDA/CRS; 2001:31-46.

76. Pelto GH, Pelto PJ, Messer E (Eds): Research Methods in Nutritional Anthropology. Tokyo, Japan: United Nations University; 1989.

77. Aguirre P: Estrategias de consumo: que cómen los argentinos que comen [Consumption strategies: what do Argentinians eat]. Argentina: Centro Interdisciplinario para el Estudio de Políticas Públicas (CIEPP); 2005.

78. Rochow M, Benno V: Food taboos: their origins and purposes. J Ethnobiol Ethnomed 2009, 5:18-27.

79. Albuquerque UP, Medeiros PM, Almeida AL, Monteiro JM, Lins Neto EMF, Melo JG, Santos JP: Medicinal plants of the caatinga (semi-arid) vegetation of NE Brazil: a quantitative approach. J Ethnopharmacol 2007, 114:325-354.

80. Albuquerque UP, Oliveira RF: Is the use-impact on native caatinga species in Brazil reduced by the high species richness of medicinal plants? J Ethnopharmacol 2007, 113:156-170.

81. Albuquerque UP, Silva VA, Cabral MC, Alencar NL, Andrade LHC: Comparisons between the use of medicinal plants in indigenous and rural caatinga (dryland) communities in NE Brazil. Boletín Latinoamericano y Caribe Plantas Med y Aromáticas 2008, 7(3):156-170.

82. Almeida ALS, Medeiros PM, Silva TC, Ramos MA, Sieber SS, Albuquerque UP: Does the June tradition impact the use of woody resources from an area of Atlantic Forest in Northeastern Brazil? Funct Ecosystems Communities 2008, 2(Special Issue 1):32-44.

83. Araújo TAS, Alencar NL, Amorim ELC, Albuquerque UP: A new approach to study medicinal plants with tannins and flavonoids contents from the local knowledge. J Ethnopharmacol 2008, 120:72-80.

84. Ramos MA, Medeiros PM, Almeida ALS, Feliciano ALP, Albuquerque UP: Use and knowledge of fuelwood in an area of Caatinga vegetation in NE Brazil. Biomass Bioenergy 2008, 32:510-517.

85. Albuquerque UP, Araújo TAS, Ramos MA, Nascimento VT, Lucena RFP, Monteiro JM, Alencar NL, Araújo EL: How ethnobotany can aid biodiversity conservation: reflections on investigations in the semi-arid region of $\mathrm{NE}$ Brazil. Biodivers Conserv 2009, 18:127-150.

86. Nascimento VT, Sousa LG, Alves AGC, Araújo EL, Albuquerque UP: Rural fences in agricultural landscapes and their conservation role in an area of caatinga (dryland vegetation) in Northeast Brazil. Environ Dev Sustain 2009, 11:1005-1029.

87. Silva IMM S e, Marangon LC, Hanazaki N, Albuquerque UP: Use and knowledge of fuelwood in three rural caatinga (dryland) communities in NE Brazil. Environ Dev Sustain 2009, 11:833-851.

88. Cartaxo SL, Souza MMA, Albuquerque UP: Medicinal plants with bioprospecting potential used in semi-arid northeastern Brazil. J Ethnopharmacol 2010, 131:326-342. 
89. Silva FS, Ramos MA, Hanazaki N, Albuquerque UP: Dynamics of traditional knowledge of medicinal plants in a rural community in the Brazilian semi-arid region. Revista Brasileira Farmacognosia 2010, 21:382-391.

90. Medeiros PM, Almeida ALS, Silva TC, Albuquerque UP: Pressure indicators of wood resources use in an Atlantic Forest Area, Northeastern Brazil. Environ Manag 2011, 47:410-424.

91. Monteiro JM, Ramos MA, Araújo EL, Amorim ELC, Albuquerque UP: Dynamics of medicinal plants knowledge and commerce in an urban ecosystem (Pernambuco, Northeast Brazil). Environ Monit Assess 2011, 178:179-202.

92. Santos LL, Ramos MA, Silva SI, Sales MF, Albuquerque UP: Caatinga ethnobotany: anthropogenic landscape modification and useful species in Brazil's semi-arid Northeast. Econ Bot 2009, 63(4):363-374.

93. Lucena RFP, Albuquerque UP, Monteiro JM, Almeida CFCBR, Florentino ATN, Ferraz JSF: Useful plants of the semi-arid Northeastern region of Brazil - a look at their conservation and sustainable use. Environ Monit Assess 2007, 125:281-290.

doi:10.1186/1746-4269-10-50

Cite this article as: Medeiros and Albuquerque: Food flora in 17th century northeast region of Brazil in Historia Naturalis Brasiliae. Journal of Ethnobiology and Ethnomedicine 2014 10:50.

\section{Submit your next manuscript to BioMed Central and take full advantage of:}

- Convenient online submission

- Thorough peer review

- No space constraints or color figure charges

- Immediate publication on acceptance

- Inclusion in PubMed, CAS, Scopus and Google Scholar

- Research which is freely available for redistribution 